\title{
Un capítulo de historia literaria. La modernidad en busca de la escritura perdida (1950-1990)
}

\author{
Marc CHEYMOL LE GALloU \\ Instituto Francés de América Latina
}

\begin{abstract}
"Ya entramos a la era del recelo", escribió Nathalie Sarraute en un ensayo publicado en febrero de 1950 en Les Temps Modernes. ${ }^{1}$ Perdida la ilusión de una escritura inocente, a la literatura francesa de la segunda mitad del siglo xx la caracteriza la búsqueda insistente de un renuevo: el título de Giono, Regain, designaba en 1930 un anhelo que iba a transformarse en obsesión finisecular.
\end{abstract}

\section{La invención de la escritura}

1. Hasta hace poco, los europeos aprendían en la infancia que la imprenta fue inventada en 1434 por el genial Gutenberg. Sin embargo, esto sólo es cierto desde el punto de vista europeo y de su afán en considerarse fuente única de la cultura universal. En efecto, los historiadores descubrieron pruebas de una actividad editorial muy anterior. En China, durante la dinastía de los Tang, un tal Wang Kie imprimió varios libros en el año 868 de esta era; en Japón, un siglo antes (770 d. C.), un millón de ejemplares de plegarias fueron impresas para distribuirse en los templos del país. Si bien es posible saber con precisión la fecha, o las fechas, de la invención de la imprenta, no es posible, en cambio, mencionar la fecha exacta de algo mucho más importante: la invención de la escritura.

Sólo un dios o un semidiós fue capaz, según la leyenda, de engendrar la escritura: Ts'ang Kie en la mitología china, Thot para los egipcios. Hace aproximadamente cinco mil años, apareció la escritura en varios puntos del mundo: Babilonia, Egipto, el valle del Indo, China. Se admite generalmente que fue gracias al ingenio de los sumerios de la ciudad de Uruk, en el cuarto milenio antes de Cristo, y que ese hallazgo tan

I Este ensayo daría su título al libro de reflexiones críticas La era del recelo: Nathalie SARRAUTE, L'ère du soupçon. París, Gallimard, 1956, p. 59. 
trascendente se habría generalizado después en la China antigua y en el antiguo Egipto. Pero en los años sesentas, los arqueólogos encontraron en Rumania tabletas con inscripciones que el carbón 14 permitió fechar en la época neolítica -es decir, para aquella región, en el sexto o quinto milenio antes de Cristo.

En Mesoamérica, los primeros rastros grabados en piedra tienen aproximadamente dos mil años, mientras queda controvertida la aparición en el periodo clásico de los primeros códices sobre materias perecederas (amate, fibra de maguey, tela de algodón o piel de ganado). Los manuscritos más antiguos que se han conservado (del siglo XVI), denotan una larga tradición de escritura que se remonta por lo menos al posclásico (noveno o décimo siglo de esta era). En cuanto a la imprenta, fue introducida durante la Colonia, cuando en 1530 el virrey De Mendoza mandó traer a México la primera máquina impresora del continente americano, que sirvió a partir de 1536 para editar publicaciones religiosas.

Esas consideraciones parecerán muy alejadas de la literatura francesa contemporánea, pero están motivadas por una convicción y una evidencia: estamos hoy en el crepúsculo de la historia de esa escritura -relacionada con el nacimiento de la pintura ${ }^{2}$ - que la mano del hombre grabara o dibujara en varias materias (cera, papiro, amate) y luego imprimiera sobre papel. Parece existir un vínculo sorprendente, es más, inquietante, entre la invención de la escritura y la condición actual de las letras. Desde los años cincuentas, se perfila el fin de la era de la escritura y del libro, cuyo desarrollo ha alcanzado sin embargo niveles récores: mientras se imprimían en Francia de 30 a 40000000 de ejemplares por año en la primera mitad del siglo, este número pasa de 50 a 60 en los cincuentas, y rebasa 350000000 a mediados de los ochentas. Pero las cintas magnéticas, los discos compactos (CD-ROM, CDI o interactivo, CDV o videodisco, data-diskman, etcétera), la mensajería electrónica, las pantallas y los procesadores de textos reemplazan poco a poco las páginas escritas, que en determinados casos (revistas, ${ }^{3}$ diccionarios, bibliografías, libros de texto, e incluso novelas ${ }^{4}$ ) parecen ya obsole-

${ }^{2} C f$. Roland BARTHES, "Las dos fuentes de la pintura", "Réquichot y su cuerpo", en Lo obvio y lo obtuso. 2a. ed. Barcelona/Buenos Aires/México, Paidós, 1992, p. 218.

${ }^{3}$ Salió en enero de 1994 la primera revista francesa en CD-ROM: La vague interactive (trimestral).

${ }^{4}$ La sociedad estadounidense Voyager empezó la comercialización en Francia de reediciones sobre discos Mac-Intosh de novelas y textos clásicos, de Ronsard a Molière y a Flaubert. 
tas; ${ }^{5}$ al mismo tiempo, la palabra escritura sufre un desplazamiento de sentido: la aparición de un nuevo concepto de escritura parece haber señalado el ocaso de la civilización del libro y del papel.

El acta de nacimiento de ese nuevo concepto es el texto fundador de la modernidad literaria en Francia, El grado cero de la escritura, de Roland Barthes, de 1953. El primer capítulo se titula " $¿ Q u e ́$ es la escritura?" Según Barthes, la escritura es "la elección general de un tono, de un ethos si se quiere, y es aqui donde el escritor se individualiza claramente porque es donde se compromete. [...] la escritura es una función: es la relación entre la creación y la sociedad, el lenguaje literario transformado por su destino social". ${ }^{6}$

La reivindicación del compromiso remite a Jean-Paul Sartre, quien publicara en 1947 el libro más importante de la posguerra respecto a la conceptualización de la literatura: ¿Qué es la literatura? Roland Barthes, "el menos ingrato de sus discípulos estructuralistas", 7 empezó a concebir su primer ensayo en ese mismo año; es significativo el nuevo giro interrogatorio: "¿Qué es la literatura?" (Sartre, 1947) se convierte en "¿Qué es la escritura?" (Barthes, 1953). Este desplazamiento inaugura, en los cincuentas, una nueva concepción de la literatura que determina y explica el destino ulterior de las letras. A partir de ese momento, y no sólo en la obra de Barthes, la escritura jugará en efecto "un papel casi obsesivo"8 en la crítica y la creación literarias.

2. La vida de las formas artísticas está sometida a una metamorfosis casi insensible, donde una materia proteica evoluciona, prolifera o se debilita

5 Después de los estadounidenses, los editores franceses se lanzan en la edición multimedia. Se estimó en 1993 a 120000 el número de lectores de CD-ROM en Francia (14\% de los hogares tienen una microcomputadora) y a menos de 100000 el número de CD-ROM vendidos en este mismo año, pero se prevé, para 1995, 1000000 de lectores de discos multimedia.

${ }^{6}$ R. BARTHES, El grado cero de la escritura. [9a. ed.] Trad. de Nicolás Rosa. México, Siglo $\mathrm{XXI}, 1987$, pp. 21-22. La escritura toma su sentido dentro de una redefinición de la lengua y el estilo. El inicio del libro de Barthes fue fundamental para precisar, en aquel año, los papeles del escritory el crítico: "Se sabe que la lengua es un conjunto de prescripciones y costumbres, comunes a todos los escritores de una misma época". Barthes define después el estilo como emanación del cuerpo del autor, es decir, como lo más personal y lo más singular. "Entre el idioma y el estilo, hay lugar para otra realidad formal: la escritura".

${ }^{7}$ Geneviève IDT, "Sartre mythologue: du mythe au lieu commun", en 7 Autour de JeanPaul Sartre. Littérature et philosophie. París, Gallimard, 1981 (Idées), pp. 117-118.

${ }^{8}$ R. BARTHES, El grano de la voz. Trad. de Nora Pasternac. México, Siglo XXI, 1983, p. 163. 
a un ritmo variable según los países, las áreas, los géneros. Sin embargo, los años cincuentas pueden ser considerados como el principio de nuestra modernidad literaria, porque la fecha señala una ruptura. Si bien en los cuarentas marcan a la literatura una conflagración mundial, la crisis moral que engendró y sus manifestaciones literarias (filosofía del absurdo y existencialismo), a partir de 1950 una mayoría de escritores afirma la voluntad de hacer "borrón y cuenta nueva" luego del trauma psíquico de la guerra. Europa se concentra en la tarea de reconstrucción; la literatura aspira a desligarse del pasado, a olvidar los temas dramáticos o pesimistas, ${ }^{9}$ y a mirar decididamente hacia el porvenir.

La noción de escritura reemplaza no sólo la de literatura (Barthes versus Sartre), sino también la de género literario. Jean-Marie Le Clézio afirmará: "La poesía, la novela, el cuento, son extrañas antiguallas que ya no engañan a nadie - 0 a casi nadie. ¿Poemas? ¿Relatos? ¿Para qué? La escritura, ya no queda más que la escritura, la escritura sola, que tantea con sus palabras, que investiga y describe con profundidad y detalles, que se aferra, que trabaja la realidad sin complacencia". ${ }^{10}$

He aquí una primera característica de la literatura francesa contemporánea: la frontera entre los géneros tradicionales tiende a desvanecerse.

Segunda característica: se enjuician el prestigio del autor y su conciencia como instancia principal de la creación literaria. Desde siglos, se vivía con un mito del Autor, que podia tomar varias formas. Boileau, al teorizar la actividad del escritor clásico, pretendía: "Lo que concebimos bien se enuncia con claridad / Y las palabras para decirlo llegan con fluidez". ${ }^{11}$

Otras formas obsoletas de la confianza en un autor omnipotente: el mito del genio en la época romántica, o el mito del narrador omnisciente en la novela de los siglos XIX y XX.

En cambio, al generalizarse las ciencias sociales a lo largo del siglo $\mathrm{XX}$, se descubre que la conciencia no es siempre conciencia de algo, y la crítica literaria se concentra en el examen del texto. En él se manifiestan fuerzas que trabajan a espaldas del escritor: fuerzas inconscientes, sociopolíticas, ideológicas o propiamente textuales. La atención se

${ }^{9}$ Salvo excepciones, como las primeras novelas de Patrick Modiano: La place de l'étoile (1968) y La ronde de nuit (1969). Modiano escribió el guión de Lacombe, Lucien (Louis Malle, 1974). Su novela Rue des boutiques obscures obtuvo el Premio Goncourt en 1978.

10 Jean-Marie LE Clézio, La fièvre. París, Gallimard, 1965, p. 8.

${ }^{11}$ N. BolleAU, Art poétique (1674), canto I, vv.153-154. 
desplaza del autor a la escritura. En Raison de la critique pure, Gérard Genette escribe:

Como ya dije muchas veces, el escritor es aquel que no sabe ni puede pensar fuera del silencio y del secreto de la escritura, aquel que sabe y siente en cada momento que, cuando escribe, no es él quien piensa su lenguaje; al contrario, sabe y siente que es su lenguaje quien lo piensa en él, y lo piensa fuera de él. De modo que nos parece evidente que el crítico sólo será plenamente crítico si entra también en lo que debemos llamar el vértigo, o si se prefiere, el juego fascinante y mortal de la escritura. ${ }^{12}$

Transformado en simple scriptor ${ }^{13}$-en la jerga de los años sesentas-, el autor ya sólo es un modesto escriba, un instrumento únicamente capaz de transcribir. En su sentido más moderno, la palabra escritura reencuentra así su sentido propio.

Al investigar e ilustrar nuevas posibilidades del lenguaje, la literatura que va de los años cincuentas a los noventas se revela ampliamente experimental y una serie de fórmulas traducen ese empeño en la novedad. Existieron el tiempo de los "nuevos novelistas" (años cincuentas), el de los "nuevos críticos" (años sesentas), de los "nuevos filósofos" (años setentas), y ahora el "posmodernismo" apoyado en la triunfante ideología neoliberal. A la "nueva novela" y al "nuevo teatro" se les llamó también "antiteatro" y "antinovela": Claude Mauriac habló así, jugando con las palabras, no de la literatura contemporánea, sino de la aliteratura contemporánea — con el mismo prefijo que opone "anormal" a "normal" - como si a esta "aliteratura" la caracterizara cierta negación o destrucción de aquella. ${ }^{14}$

Otra característica: entre los cincuentas y noventas, la creación literaria no puede separarse de la reflexión sobre la naturaleza y la función de la literatura. Creación y crítica quedan tan intimamente entrelazadas que poemas y novelas son por igual libros de crítica; por otra parte, críticos como Roland Barthes subrayan que "ese canto sobre el canto sólo podrá convencer si se desenvuelve con el mismo rigor y bajo la misma forma de la obra que pretende comentar; la reflexión sobre 31.

${ }^{12}$ Apud Jean Ricardou, Pour une théorie du nouveau roman. Paris, Le Seuil, 1971, p.

${ }^{13}$ Georges Perec usó esa palabra de manera irónica, mientras los "nuevos críticos" la empleaban con mucha seriedad.

${ }^{14}$ Claude MAURIAC, L'alittérature contemporaine. Paris, Gallimard, 1958. 
la escritura no puede ser sino escritura". ${ }^{15}$ Como Barthes - un moderno Montaigne,$-{ }^{16}$ los críticos llegan a ser auténticos creadores: reintroducen la literatura en el ensayo.

3. Sin embargo, todos los intentos para reinventar la escritura, por representativos que sean de la modernidad, no deben hacer olvidar las vanguardias de la primera mitad del siglo XX: el cubismo y el surrealismo, por ejemplo, prepararon esas innovaciones; los supuestos descubrimientos de la posguerra recogen también la herencia de la $N$. $R$. F., de Gide y Valéry en particular. Además, es preciso señalar una abundante literatura de inspiración tradicional, de calidad desigual pero no desprovista de interés y que, lejos de formalizar una ruptura, se empeña en perpetuar modelos a toda prueba desde la más remota tradición literaria. Por lo tanto, cabrá preguntarse si hay realmente una invención de la escritura en la literatura francesa desde los años cincuentas, o si por el contrario la estéril repetición de esquemas sólo refleja una impotencia para inventar formas propias de nuestro momento histórico.

En 1960, Julien Gracq declaró: "imposible elaborar cualquier tipo de inventario crítico serio de la literatura moderna [sin tropezar con dos de ellos:] el manual literario encerrado en los valores tradicionales, o bien el panorama de los valores del momento".

El presente ensayo sólo propone un esquema que permita situar las obras relevantes producidas después de 1950 , sin criterios de exhaustividad y sin ceder a la facilidad de un inventario en forma de catálogo. Voluntaria o involuntariamente, se pasarán por alto muchos nombres importantes, muchos "valores del momento", en beneficio de obras ejemplares que elegimos para nuestro propósito. Los ejemplos aquí citados deben ser considerados precisamente como tales. Más que un panorama, se desea un examen de la producción contemporánea a la luz de algunas ideas generales.

Cabe mencionar que de manera deliberada y tal vez artificial, decidí limitarme a los escritores del hexágono, descartando así las otras literaturas de expresión francesa, tanto europeas (belga, suiza, etcétera) como americanas (de Quebec, de las Antillas) y africanas (África del Norte,

${ }^{15}$ R. BARTHES, "Mesas redondas", en Casa del Tiempo. Trad. de Víctor Hugo Piña Williams. México, UAM, noviembre, 1993, p. 7.

${ }^{16}$ La publicación de las Obras completas de Roland Barthes, iniciada en 1993 por las Éditions du Seuil, permite comprobarlo; rinde plena justicia a los talentos estilísticos de Barthes. (Cf. Le Magazine Littéraire, núm. 314. Paris, octubre, 1993.) 
África Negra). A pesar de su importancia, o mejor dicho por su misma importancia, no considero aquí a Georges Simenon, ni a Philippe Jacottet, a Aimé Césaire ni a Édouard Glissant, a Mohammed Dib, Rachid Boudjedra o Leopold Senghor. Son capítulos aparte en la historia literaria, y por ello se evitará presentarlos como remolque de una literatura metropolitana.

\section{Los géneros renovados}

\section{La nueva novela}

A pesar de 10 que comúnmente se cree, la narrativa de la escuela del "nouveau roman" no fue escrita a partir de preceptos: la teoría se constituyó al mismo tiempo, o después de la experimentación de nuevas formas novelísticas. Para una nueva novela, el ensayo de Alain RobbeGrillet, quien destaca como teórico en el grupo, no apareció sino en 1963 y los otros textos teóricos capitales para la comprensión de este movimiento son más tardíos. ${ }^{17}$

El término de "nueva novela" no designa una escuela, ni siquiera un grupo definido y constituido de escritores que trabajarian con el mismo enfoque; no es más que una palabra cómoda, que incluye a todos los que buscan nuevas formas novelísticas susceptibles de expresar (o de crear) nuevas relaciones entre el hombre y el mundo, todos los que están decididos a inventar la novela, es decir, a inventar el hombre. ${ }^{18}$

Ni siquiera se define el grupo por una generación. Varios de sus integrantes habían empezado a publicar antes de la guerra: Tropismos, la novela que hiciera famosa a Nathalie Sarraute en los años cincuentas, apareció en 1938 con el Murphy de Samuel Beckett, es decir, el mismo año que La náusea de Jean-Paul Sartre. A pesar de grandes diferencias estilísticas, temáticas y cronológicas, la "nueva novela", en un sentido amplio, forma un conjunto cuya unidad aparecerá al destacar algunas características comunes.

17 Problemas de la nueva novela (Problèmes du nouveau roman, 1967) seguido por Para una teoria de la nueva novela (Pour une théorie du nouveau roman, 1971) de Jean Ricardou, quien fue un escritor de la segunda generación de la nueva novela.

18 Alain RoBBE-GRILLET, Pour un nouveau roman. París, Éditions de Minuit, 1963 (Critique), p. 9. (El subrayado es mío.) 
Una casa editorial simboliza el grupo de los nuevos novelistas: las Éditions de Minuit, que gracias al amplio criterio de Jérôme Lindon y de su director literario, Georges Lambrichs, ${ }^{19}$ publicaron casi todas las obras de la nueva novela bajo la misma elegante portada blanca con letras azules, ${ }^{20}$ réplica de la colección blanca de Gallimard, que con la celebérrima portada color crema con título rojo había presentado obras clásicas del siglo XX. La nueva novela se consolidó a partir de 1953, cuando salieron, casi al mismo tiempo que el ensayo de Roland Barthes, ${ }^{21}$ Watt y El innombrable (de Samuel Beckett), así como Las gomas (Les gommes) de Alain Robbe-Grillet; Martereau, de Nathalie Sarraute y Los caballitos de Tarquinia (Les petits chevaux de Tarquinia), de Marguerite Duras. Desde entonces, las "nuevas novelas" aparecen cada año, una tras otra. ${ }^{22}$ Vino después la era de los reconocimientos: en 1957, La modificación recibió el Premio Renaudot. Beckett esperaría hasta 1961 el Premio Internacional de Literatura, compartido ese año con Borges. La atribución del Nobel a Samuel Beckett (1969) marcó el apogeo de la nueva novela, que duraria hasta el éxito internacional de la obra de Marguerite Duras a mediados de los ochentas -en particular, de $E l$ amante $^{23}$-, y otro Nobel, otorgado a Claude Simon en 1985. Esos reconocimientos confirmaron la vigencia de una corriente que desde los cincuentas no ha dejado de ser motivo de controversias.

Sin abordar detalladamente un tema de esa complejidad, quisiera tan sólo mostrar la nueva novela en su búsqueda de una escritura nueva. Básicamente, el punto común entre esos novelistas es el rechazo de la concepción tradicional de novela, que en la primera mitad del siglo había

19 Georges Lambrichs (falleció en 1992) pasó a Gallimard después de pelearse con Jérôme Lindon y dirigió la revista Les Cahiers du Chemin, que publicó lo mejor de la literatura francesa entre 1965 y 1975.

${ }^{20}$ Para las reediciones recientes, Minuit presenta ahora estas obras con una portada figurativa, que por ser más amena no deja de ser un contrasentido, tratándose de obras que rechazan el principio de la figuración.

${ }^{21}$ El grado cero de la escritura, vid. supra, p. 163, n. 6.

22 1954, Pasaje de Milán (Passage de Milan) de Michel Butor; 1955, El mirón (Le voyeur) de Robbe-Grillet; 1956, El horario ( $L$ 'emploi du temps) de Michel Butor; 1957, La celosia (Lajalousie) de Robbe-Grillet, La modificación (La modification) de Michel Butor y El viento (Le vent) de Claude Simon; 1958, Moderato cantabile de Marguerite Duras y La hierba ( $L$ 'herbe) de Claude Simon. Fueron cinco años de una producción muy intensa de los amigos de Jérôme Lindon, que dieron el impulso a una verdadera corriente literaria, que la crítica tuvo que tomar en cuenta.

${ }^{23} L$ 'amant, 1984, Premio Goncourt. Duras quiso reeditar este éxito con L'amant de la Chine du Nord, 1990. 
conocido brillantes ilustraciones como las de Mauriac, Bernanos, Giono, Malraux, etcétera. Ya Paul Valéry, André Gide ${ }^{24}$ y más recientemente Jean Paul Sartre ${ }^{25}$ habían cuestionado la validez del relato tradicional; este último opuso a Mauriac la práctica de los novelistas estadounidenses, en particular la de John Dos Passos, mostrando asi una revolución en el "punto de vista" del narrador. La nueva novela, que recoge los frutos de esa innovación técnica, será conocida durante un tiempo como "escuela de la mirada". Marguerite Duras también se había declarado de la escuela estadounidense mucho antes de la constitución de la nueva novela: antes de la guerra, varias de sus novelas se emparentan directamente con el neorrealismo de Steinbeck, por ejemplo.

Pero fue Roland Barthes quien suscitó un cuestionamiento más vigoroso del relato tradicional al formular con gran claridad, en El grado cero de la escritura, las reglas básicas de la novela: uso del pronombre "él" y del pretérito (en francés passé simple). Barthes recalcó que ambos recursos literarios recrean en el relato personajes individualizados, protagonistas de una serie de acciones congeladas en un orden determinado. Claude Mauriac, que se integraría también al grupo de los impugnadores de la novela, simbolizó el recelo hacia la narrativa tradicional por un título: La marquesa salió a las cinco. Retomaba de manera emblemática las reticencias que Paul Valéry había ya compartido, según el testimonio de André Breton. ${ }^{26}$ En efecto, la palabra insane era el inicio típico de un relato tradicional, a partir del cual la tarea del novelista consiste en darle a su marquesa cierta identidad (una descripción física y psicológica, una familia, una historia, etcétera), e inventar una serie de acciones atribuibles con verosimilitud a dicha marquesa: ¿Por qué y para qué salió a las cinco?

Esas ideas sencillas explican la fisonomía tan particular de la nueva novela.

24 En Los falsos monederos, 1924.

${ }^{25}$ En Situaciones, 1947.

${ }^{26}$ C. MAURIAC, La marquise sortit à cinq heures, 1961. En el primer Manifiesto del surrealismo (1924), André Breton cuenta: “M. Paul Valéry proposait dernièrement de réunir en anthologie un aussi grand nombre que possible de débuts de romans, de l'insanité desquels il attendait beaucoup. [...] Une telle idée fait encore honneur à Paul Valéry qui, naguère, àpropos des romans, m'assurait qu'en ce qui le concerne, il se refuserait toujours à écrire: La marquise sortit à cinq heures. Mais a-t-il tenu parole?" (André BRETON, Manifestes du surréalisme. París, Gallimard, 1972 [Idées], p. 15.) 


\section{Desaparición del personaje}

A principios del siglo Xx, en las obras de James Joyce y Robert Musil por ejemplo, se inicia la desagregación del héroe. Claude Ollier intituló una de sus piezas radiofónicas La muerte del personaje (La mort du personnage): ese elemento esencial de la narrativa es efectivamente el que desaparece en los experimentos de la nueva escritura. Muchas veces, no tiene nombre y sólo se le identifica por un lacónico "el hombre" en las novelas de Alain Robbe-Grillet, o por una mayúscula ("A." en $L a$ celosia): es más, ninguna descripción física ayuda a individualizarlo y se vuelve irrisorio símbolo de cualquiera de nosotros. Pero lo más característico se encuentra tal vez en la obra de Beckett, que presenta un abanico de personajes deshumanizados, larvarios, reducidos en sus mejores momentos - como la esposa de Krapp - a un "montón de órganos en desuso" 27 , en otros casos límite, a una boca que niega su propia identidad (Not $I$ ), y a la voz balbuceante de El innombrable o Cómo es. Este aspecto suscitó significativamente acérrimas críticas, porque socavaba el protocolo y la dignidad de la literatura. La degradación del personaje en la obra de Beckett llega no sólo a la puesta en escena de vagabundos o tullidos condenados a reptar en el lodo o a quedar inmovilizados en botes de basura, sino también a una duda sobre la identidad misma del sujeto: ¿quién es "yo" en El innombrable? ¿Murphy, Molloy, Malone o Samuel Beckett?

\section{Rechazo del pronombre "él"}

Butor lanza también un desafío a las tradiciones narrativas con el extraño "usted" que, desde la primera frase de La modificación, suena para el público como un insulto o una agresión, a pesar de ser una fórmula de cortesía. Sobre todo, envuelve al lector en la narración e incluso en la composición del libro. Realiza con éxito una intención obvia 0 implícita que existe en casi todas las "nuevas" novelas: concluir, en el marco de este recelo que describió Nathalie Sarraute en el ensayo fundador ya mencionado, un nuevo pacto entre el productor y el consumidor de la literatura (es lo que explica la frecuente dimensión tautegórica de las novelas de esta época). ${ }^{28}$ Beckett prefirió por su parte un yo que

${ }^{27}$ Eleuthéria, obra inédita (1947) conservada en las Éditions de Minuit.

${ }^{28}$ En oposición a alegórica (obra que remite por medio del símboblo, por ejemplo, a una realidad, una idea, un personaje, exterior a ella), se dice tautegórica una obra que remite a sí misma, como Los falsos monederos de André Gide, La modificación de Michel Butor - procedimiento que fue común en la época barroca, especialmente en el teatro ( $E l$ sueño de una noche de verano, Hamlet de Shakespeare, etcétera). 
llevaba a sus últimas consecuencias el yo desencarnado de Proust -ese yo que constituye la dimensión más revolucionaria de En busca del tiempo perdido y explica por qué "Proust es el fundador de toda esa parte tan importante de la literatura moderna, que tiene por objeto el lenguaje mismo". ${ }^{29}$ La nueva novela utiliza muchas veces un yo igualmente alejado del yo empleado en la autobiografía y del yo que en la novela naturalista introduce un personaje más de la narrativa tradicional.

Desintegración progresiva del contexto espacial

En la obra de Beckett, son particularmente notables la progresiva desintegración del espacio de la narración, la presencia creciente e invasora de las tinieblas, la incertidumbre espacial que lleva no sólo a los personajes, sino al lector y al propio narrador, a dudar de la realidad que enfrenta. Pero este recurso caracteriza también las novelas y las películas de Alain Robbe-Grillet y Marguerite Duras, así como El innombrable o la última obra publicada de Beckett, Sobresaltos ("como alguien en un sitio desconocido en busca de la salida [...] mismo sitio que aquél desde el cual cada día se iba a errar"). ${ }^{30}$

\section{Desagregación de la secuencia narrativa}

Roland Barthes expresó que la práctica de la discontinuidad en el relato, generalizada por Butor a partir de Grados (Degrés, 1960) y sobre todo de Mobile (1962), "hirió la idea misma de libro". ${ }^{31}$ Sin embargo, Barthes mostró también que la aparente discontinuidad encubre "un continuum del discurso que es inmediatamente perceptible". Esta práctica es así emblemática del esfuerzo de la nueva novela por presentar la literatura como "un código que es menester descifrar". ${ }^{32}$ En el laberinto de RobbeGrillet, la repetición de las acciones pervierte también el orden del relato y nos induce en un laberinto del tiempo que es, en realidad, el laberinto de la escritura.

La desagregación de la secuencia ordenada de los acontecimientos que configuraban un relato y organizaban un mundo estructurado se da

29 Roger LAPORTE, “La naissance de la littérature", en La Nouvelle Revue Française. París, julio, 1967, pp. 81-91.

${ }^{30}$ Samuel BECKETT, Soubresauts. París, Éditions de Minuit, 1989, 32 pp. (Sobresaltos. Trad. de Antonio Marquet. México, UAM-A, 1990, pp. 14-18.)

${ }^{31}$ R. BARTHES, “Littérature et discontinu”, en Critique, 1962. Reed.: Essais critiques. París, Le Seuil, 1964 (Tel quel), p. 175.

32 "C'est précisément cela, la littérature: un code qu'il faut accepter de déchiffrer". (R. BARTHES, Essais critiques, p. 181.) 
en la obra de Beckett, especialmente a través de la perversión del tiempo. Es sensible desde Molloy; en Cómo es, el tiempo se estira hacia el infinito; en El despoblador, el tiempo parece suspendido - "en caso de que esta noción se mantenga válida", como lo apunta obsesivamente Beckett. Así, en la obra de los "nuevos novelistas", el relato no tiene pies ni cabeza: su lógica está en otra parte.

\section{Búsqueda de la neutralidad del narrador}

Las primeras obras de Marguerite Duras, por su búsqueda de la neutralidad en la captación de estados anímicos que vacilan entre conciencia e inconciencia, se aproximan a los experimentos de Claude Simon y Alain Robbe-Grillet. Pero es Nathalie Sarraute quien ofrece el ejemplo más característico al pretender traducir por medio de una escritura neutral los estados anímicos sutiles que llamó tropismos ("fluctuaciones de la conciencia [plasmadas] en un lenguaje que refleja todas las sensaciones oscuras, contradictorias, que nos atraviesan"). ${ }^{33}$

Fue precisamente esa neutralidad la que Roland Barthes acababa de nombrar "el grado cero de la escritura" o "escritura blanca", "un estilo de la ausencia que es casi una ausencia ideal de estilo", ${ }^{34}$ inaugurada por El extranjero de Camus pero cuyo ejemplo más logrado es tal vez la escritura despersonalizada de Samuel Beckett.

\section{Segunda generación de la nueva novela}

Por los años sesentas, se integraron a la "nueva novela" jóvenes escritores como Jean Ricardou, Jean Thibaudeau, Jean-Pierre Faye, Marcelin Pleynet, Maurice Roche y Philippe Sollers.

Maurice Roche es probablemente, desde la publicación de Compact en 1966, el escritor que puso en tela de juicio de la manera más radical las estructuras de la narrativa, llevando a sus últimas consecuencias la podredumbre de la escritura contemporánea; pero con Drama (Drame, 1965), y luego Lógicas (Logiques, 1968), Números (Nombres) y Leyes (Lois, 1972), fue Sollers quien apareció como el símbolo de la vanguardia literaria, espeluznante para los tradicionalistas. Sus primeras obras, El desafio (Le défi, 1957) y El parque (Le parc, 1958), relativamente accesibles, fueron advertidas y alabadas por François Mauriac, pero después renegados por el propio Sollers. Su afición por el rigor cientí-

${ }^{33}$ Frédéric-Yves JEANNET, "Nathalie Sarraute o la conversación reinventada", en "La Jornada Semanal”, núm. 235, supl. de La Jornada. México, 12 de diciembre, 1993, p. 38.

${ }^{34}$ R. BARTHES, El grado cero de la escritura, pp. 78-80. 
fico y las matemáticas, visible en sus títulos y compartido por otros escritores de la época (Queneau, Perec, Le Lionnais, Roubaud, Bonnefoy, Denis Roche), manifiesta el recelo hacia la literatura institucionalizada y la consecuente mala conciencia que experimentan los productores de la literatura. ${ }^{35}$

Sollers, Ricardou y sus amigos fueron a la vez novelistas y críticos que se sumaron a la ya reconocida escuela de "la nueva crítica", integrada por Roland Barthes, Gérard Genette, Jean-Pierre Richard, Jean Rousset y Tzvetan Todorov, así como Greimas y la semiótica, Julia Kristeva y la semanálisis, etcétera. Representaban en realidad una familia intelectual más amplia, la de los "estructuralistas", cuya caracteristica fue abarcar en la reflexión sobre la literatura todas las ciencias humanas, tanto la lingüistica (desde Saussure, Chomsky, etcétera) como el psicoanálisis (Jacques Lacan), la etnología (Claude Lévi-Strauss), la filosofía (Michel Foucault, Louis Althusser), a los que se agregarian alrededor del 68 Jacques Derrida, Michel Serres, Gilles Deleuze y Félix Guattari. En los setentas, los novelistas de la primera generación parecen alejarse por igual del género novelístico, o abandonarlo definitivamente: Michel Butor cierra un ciclo con Intervalos, subtitulado Anécdota en expansión (1970), y prefiere dedicarse a la crítica literaria o artística. A partir de ¿Los escucha? (Yous les entendez?, 1972) y hasta Tú no te quieres (Tu ne t'aimes pas, 1989), Nathalie Sarraute "ha descartado casi por completo la anécdota", advierte Frédéric-Yves Jeannet, quien agrega: "aqui la novela en sí desaparece y la escritura se reduce a una sucesión de fragmentos hilados por un tema, semejante al tema musical o poético". ${ }^{36}$

Mientras la nueva novela se diluye en el ensayo o en la autobiografia, a la cual regresan Duras y Sarraute, a la generación del relevo la integran pensadores que sólo prolongan en la novela su reflexión teórica. La filosofia y las ciencias del hombre pretenden unirse en un proyecto único, bajo el signo del lenguaje. ${ }^{37}$ La compenetración entre literatura y

${ }^{35}$ Desde 1981, con Mujeres (Femmes), Sollers parece haber cambiado de estilo al cambiar de editorial: pasando a la casa Gallimard, pudo entrar también al libro de bolsillo (gracias a la colección Folio), lo cual significó una inmediata extensión de su público. En esa nueva manera, publicó Le coeur absolu (1987), Les folies françaises (1988), Lelys d'or (1989), La fête à Venise (1991), Le secret (1992).

${ }^{36}$ F. Y. JEANNET, “Nathalie Sarraute o la conversación reinventada”, en op. cit., p. 43.

${ }^{37}$ Ese proyecto llamado "le tournant linguistique", ha dejado una herencia importante, aunque su validez sea cuestionada en la última década. (Cf. Thomas PAVEL, Le mirage linguistique. Essai sur la modernisation intellectuelle. París, Éditions de Minuit, 1988. 210 pp.) 
ciencias sociales llega a una identificación casi completa y por ello estas novelas reciben a veces el nombre genérico de "novela estructuralista". Se trató de llevar a su punto extremo los presupuestos del grupo de las Éditions de Minuit, ${ }^{38}$ pero su principal expresión en el campo editorial fueron las Éditions du Seuil, con la colección y la revista Tel Quel, dirigidas por Philippe Sollers. En las obras "telquelistas", o "telquelizantes" - como ya se dijo entonces-, la elusión del personaje y el rechazo de la preocupación realista beneficia al puro lenguaje: ya no representa nada, ya no hay argumento. La novela deja de ser la aventura de unos personajes para convertirse en una aventura de la palabra, o sea de la escritura. La representación que se da èntonces es la del juego del lenguaje, de la ilusión de la escritura. Sollers escribe en Drama: "Estamos ahora en el proscenio de la palabra. Ésta se descubre interior y exterior a la vez, dependiente ya de un coro (el pronombre él), ya de un individuo que se designará con un yo".

Roger Laporte, ${ }^{39}$ aun proponiendo un nuevo género que sería la "biografia", ofrece en La veille (1963), Une voix de fin silence I(1966), Pourqoui (1967) y sobre todo Une vie (1986) una obra novelística que solicita directamente la reflexión sobre la escritura.

Varios novelistas nacidos en los años cuarentas, revelados en los sesentas en el contexto de la nueva novela, quedan al margen de Tel Quel, aunque su escritura rompe también con la construcción tradicional del relato y aprovecha los aportes de la nueva escritura. Desde Récidive (1967) e Interdit de séjour (1969), Tony Duvert, nacido en 1945, elige transcribir en un molde moderno el otro lado del erotismo y la sexualidad, y prosigue así la reivindicación de Jean Genet al que remite ostensiblemente el Journal d'un innocent (1976), una respuesta desculpabilizada, treinta años después, al Journal du voleur (1946).

En una dirección diferente, Jean-Marie Le Clézio también propuso nuevas formas de la novela e intentó crear un estilo propio. Revelado al público por el Renaudot que en 1963 premió Le procès-verbal, Le Clézio llegó a conquistar un público amplio sólo en los años ochentas. Con

38 Jean Ricardou ha estudiado la relación entre Tel Quel y la "nueva novela", apuntando "la radicalización por parte de Tel $Q$ uel de la actividad de la nueva novela": "en su diario común contra el dogma de la representación, la actividad de la nueva novela es repetida e incrementada por Tel Quel'. (Pour une théorie du nouveau roman. París, Le Seuil, 1971, p. 265.)

39 Nacido en 1925. Cf. F. Y. JEANNET, “Roger Laporte à l'épreuve du silence", en Digraphe, núm. 46. París, Mercure de France, diciembre, 1988, pp. 75-85. 
Désert (1980), Le chercheur d'or (1985) y Voyage à Rodrigues (1986), retoma la tradición novelesca, en particular de la novela de aventuras, con una dimensión mítica. Incluyendo un libro de cuentos, Printemps et autres saisons (1989), y una última novela: Onitsha (1991), las obras recientes de Le Clézio se pueden leer como una fábula del retorno al origen, como una metáfora de la civilización occidental traducida a un lenguaje esplendoroso que festeja la unión del sujeto con la belleza de la vida. Le Clézio, quien ha vivido en México y se ha convertido en un apasionado de este país sin olvidar por ello sus raices mauricianas, ${ }^{40}$ ha amalgado en Francia Oriente y Occidente, dos horizontes lejanos, en una búsqueda simbólica. Esas últimas obras aparecen como una búsqueda estilística y ética amparada por la figura ejemplar de Sahagún, cuyo deseo proselitista se convirtió en recuperación apasionada de la cultura náhuatl. La sed de oro de los conquistadores y la curiosidad intelectual de los humanistas dan la clave susceptible al mismo tiempo de explicar y salvar el mundo de hoy. Recogiendo la herencia de $\operatorname{Rimbaud}^{41}$ y de los surrealistas ${ }^{42}$ que encontraron en países como México valores que el mundo occidental ha perdido, Le Clézio pretende: "El encuentro con el mundo indio ya no es un lujo hoy en día. Se volvió una necesidad para quienes quieren entender lo que pasa en el mundo moderno". ${ }^{43}$

Le Clézio ha editado en francés El libro de los libros de Chilam Balam y evocado en un texto curioso y conciso, Trois villes saintes (1980), tres ciudades mayas desaparecidas: Chancah, Tixcacal y Chun Pom. Tradujo también en el ensayo su pasión por México, desde Haï hasta El sueño mexicano y Diego y Frida. ${ }^{44}$

${ }^{40}$ Las dos últimas novelas están fundadas sobre la aventura de la rama paterna de Le Clézio, colonos que se instalaron en el siglo XVIII en la isla Mauricio, posesión francesa del océano Indico, así como en la vecina isla Rodrigues. Ambas pasaron a sercolonias inglesas después de la derrota de Napoleón I (1810-1815).

${ }^{41}$ Rimbaud pensaba el Oriente en los mismos términos. Cf. Una temporada en infierno: "Mandaba al diablo las palmas de los mártires, los esplendores del arte, el orgullo de los inventores, el ardor de los plagiarios; me volvía a Oriente, a la sabiduría primera y eterna". (L'impossible. Oeuvre-Vie. Ed. de Alain Borer. París, Arléa, 1991, p. 440.)

${ }^{42}$ En particular, Antonin Artaud en su conferencia "Surrealismo y revolución"(Oeuvres complètes, t. vill. París, Gallimard, 1971, p. 174). Cf. Luis Mario SCHNEIDER, México y el surrealismo (1925-1950). México, Arte y Libros, 1978, p. 61.

43 J. M. LE Cléżo, Hai. París, Champs/Flammarion, 1987, p. 11.

44 J. M. Le Clézlo, Hai. Ginebra, Skira, 1971; Prophéties de Chilam Balam. París, Gallimard, 1976; Relation de Michoacán. París, Gallimard, 1984; Le rêve mexicain ou la pensée interrompue. París, Gallimard, 1988; Diego et Frida. París, Stock, 1993. 


\section{El nuevo teatro}

Los escritores de las Éditions de Minuit y los de Tel Quel no se limitaron a la crítica literaria y a la novela: transformaron también el lenguaje teatral.

La figura sobresaliente del nuevo teatro es la de un importante narrador, Samuel Beckett, quien da a la expresión del absurdo contemporáneo su mayor resonancia en la escena: Esperando a Godot (En attendant Godot, 1952), el extraordinario y conmovedor Oh les beaux jours! (1963) y por fin Catastrophe et autres dramaticules (1982). La primera pieza fue, junto con La cantante calva (La cantatrice chauve) de Eugène Ionesco, la chispa que prendió la pólvora de la vanguardia en los años cincuentas. Luego, mientras Ionesco evolucionaba hacia un teatro más generoso y enriquecido con una verdadera dimensión shakespeariana, como en El rey muere, evidente réplica de $E l$ rey Lear - tragedia simbólica de la agonía de los valores contemporáneos (Le roi se meurt, 1962)-, Beckett acentuaba cada vez más su pesimismo y su exigencia literaria, hasta llegar a un silencio desengañado.

Cabe mencionar también a Claude Simon (La separación), a Robert Pinget (Lettre morte, 1959), a Romain Weingarten (L'été, 1966) a Roland Dubillard (La maison d'os, 1962), a François Billetdoux, Arthur Adamov, Arrabal y muchos más. La obra poética y novelística de Jean Genet, escrita en los años de la guerra y la inmediata posguerra ${ }^{45}$ e inscrita en la ruptura - social y moral -, se continúa con una serie de obras dramáticas que mezclan la ilusión, lo perverso y lo sagrado en una verdadera asunción de la ética artaudiana del teatro de la crueldad: $E l$ balcón (1956), Los negros (1958), Los biombos (1961) representan una propuesta teatral concebida como una comunión que desembocará en la rebeldía y la revolución.

El "séptimo arte" llega también a ser terreno de expresión de los impugnadores de la novela o del teatro: Beckett escribe $\mathrm{Film},{ }^{46}$ que se rueda en Estados Unidos en 1964 con Buster Keaton como único actor, bajo la dirección de Alan Schneider, y recibe el Premio de la Crítica en el Festival de Venecia (1965). Aparte de numerosas obras de teatro,

${ }^{45}$ Los poemas de El condenado a muerte (1942) cantan el deseo incandescente en alejandrinos regulares; las novelas Pompes funèbres (1944), Querelle de Brest (1944), Notre-Dame des Fleurs (1946) y Miracle de la rose (1947), evocan en una prosa lírica, a la vez barroca y cruda, personajes de ensueño cuya ambigüedad pone en tela de juicio el maniqueísmo burgués.

${ }^{46}$ S. BECKETT, Film. Trad. y pról. de Jenaro Taléns. Barcelona, Tusquets, 1975. 
Marguerite Duras se interesa especialmente en el cine, pasión que comparte con ella Alain Robbe-Grillet: ambos escriben guiones, antes de realizar sus propias películas. ${ }^{47}$

El antiteatro, como la novela correspondiente, disuelve personajes y lenguaje para enfatizar la desaparición del sujeto, y expresa así la deshumanización del arte moderno cuya dramática escenificación genera la angustia sin límites que muchas veces se expresa en la risa, su último recurso.

Pero los años setentas representaron, tanto para el teatro como para la novela, una nueva crisis.

1968 muestra una vez más las limitaciones de este teatro vanguardista. El teatro es ahora manifestación popular, toma de escena como podría hablarse de ganar la calle en una revuelta estudiantil. Ante la demanda del público, las obras de teatro se convierten en espectáculos y el autor desaparece progresivamente para dejar al director como hombre orquesta capaz de organizar y dar vida a los espectáculos. ${ }^{48}$

Al margen del continuo éxito del teatro de bulevar o el de Jean Anouilh, de las aparatosas escenografías de Robert Hossein y de la perseverancia de grandes compañías oficiales (Comédie-Française, Odéon, T. N. P. de Chaillot), la vanguardia se encuentra entonces en la práctica de tres directores: Ariane Mnouchkine, Antoine Vitez y Patrice Chéreau, quienes desplazan del texto al escenario el lugar de la modernidad. En un momento de relativa penuria creativa, en la que se erige como excepción la obra de un autor joven prematuramente desaparecido: Bernard-Marie Koltès (Combat de nègre et de chiens, 1983; Quai Ouest, 1985; Dans la solitude des champs de coton; 1987; Le retour au désert, 1988; Roberto Zucco, 1990), ${ }^{49}$ se recuperan obras clásicas, de Racine a Marivaux,

${ }^{47}$ Marguerite Duras, La musique, 1960; Détruire, dit-elle, 1969; Nathalie Granger, 1972; India Song, 1975; Baxter, Vera Baxter, 1976; Son nom de Venise dans Calcutta désert, 1976; Des journées entières dans les arbres, 1976; Le camion, 1977; Le navire Night, 1978; Les mains négatives, 1979; Césarée, 1979; Amelia Steiner, 1979; Les enfants, 1985. Guiones de Hiroshima mi amor (Alain Resnais, 1960) y Une aussi longue absence (Henri Colpi, 1961).

Alain Robbe-Grillet, L'homme qui ment, 1968; L'éden et après, 1971; Glissements progressifs du plaisir, 1974; Le jeu avec le feu, 1975; La belle captive, 1984. Guión de L'année dernière à Marienbad (Alain Resnais, 1961).

${ }^{48}$ Carlos BONFIL, "Notas sobre la creación teatral en Francia. 1970-1985", en Culturarte, núm. 2. México, mayo, 1986, p. 29.

49 Bernard-Marie Koltès es también autor de novelas: La fuite à cheval très loin dans la ville (1984); La nuit juste avant les forêts (1988); Prologue (1991). 
pasando por Shakespeare o por adaptaciones de novelas y clásicos extranjeros.

\section{Poesía y antipoesía}

Michel Butor escribió al principio de Répertoire II (1964): “desde el día en que comencé mi primera novela, durante años no redacté ya un solo poema, porque tenía la impresión de que la novela, en sus formas más elevadas, era capaz de recoger toda la herencia de la poesía antigua". ${ }^{50}$

Sin embargo, y aunque un solo libro haya sido reivindicado por el autor como tal (Travaux d'approche, 1972), se pueden considerar como textos de carácter poético los que Butor publicó en abundancia a mediados de los sesentas: las series de Ilustraciones, ${ }^{51}$ de Matière de rêves, ${ }^{52}$ Envoi, ${ }^{53}$ etcétera. Ahí la imagen, ya sea pictórica, sonora o esa compleja representación de sintesis que brindan los sueños, siempre entra como mediadora de la poesia, instaurando un vaivén entre la escritura y la expresión plástica o musical. En particular, el "relato de sueños" rebasa la tentativa de Georges Perec (La boutique obscure. 124 rêves, 1973) y llega a ser un género literario aparte -exploración de la materialidad del lenguaje, cuyas estructuras permiten construir el relato de sus sueños. Es el relato de lo imaginario en su estado más puro. Gracias a él se descubre parte del mecanismo misterioso de producción de las imágenes, cuya proliferación intenta deslindar los límites porosos de nuestra personalidad, como los "tropismos" de Nathalie Sarraute.

De Samuel Beckett, cabe también mencionar sus Poemas, reeditados con Mirlitonnades en 1978.

Francis Ponge (1889-1988), autor de Le parti-pri des choses (1942), fue considerado por Jean-Paul Sartre como el poeta del existencialismo, por los nuevos novelistas como el precursor de su movimiento y por Tel Quel como el fundador del lenguaje moderno. Es un poeta que no reconoce hacer poesía. Sus pequeños párrafos en prosa describen minuciosamente las cosas hasta agotarlas: son poemas sin lirismo, donde se percibe una gran ternura y una profunda admiración para las cosas (conchas, naranjas, caracoles, etcétera). Ponge aparece como un poeta genial por su dominio del lenguaje, que reanuda con la tradición de los blasonadores del siglo XVI y modifica radicalmente el modo de expresión

\footnotetext{
${ }^{50}$ Michel Butor, Répertoire II. París, Gallimard, 1972 (Idées), p. 7.

S1 Cuatro volúmenes, en Gallimard, col. Le chemin, 1964-1976.

52 Cinco volúmenes, en Gallimard, col. Le chemin, 1975-1985.

${ }^{53}$ Dos volúmenes, en Gallimard, col. Le chemin, 1980-1983.
} 
literaria moderno, abriendo paso tanto a las descripciones de la "nueva novela" como a los experimentos lingüísticos de Tel Quel. ${ }^{54}$

Del grupo de Tel Quel, Marcelin Pleynet con Paysage en deux (1963), Comme (1965), Stanze (1973), Plaisir à la tempête (1987), transforma la poesia en una reflexión sobre el quehacer de la escritura, considerada por la crítica como "una de las tentativas más interesantes de la poesía francesa desde la guerra". Comparten la misma tendencia otros "poetas del lenguaje", como Michel Deguy, Henri Meschonnic y Jacques Roubaud. Este último juega con los números, la tipografía y los ritmos en Trente et un au cube (1973) y, en Autobiographie chapitre dix, con la narrativa como dimensión de la poesía. Roubaud propone "un gran colaje que nos lleva de nuevo a la problemática central de la literatura actual, la del escritor-lector, citando, parodiando, escribiendo". ${ }^{55}$ Maurice Roche, el autor de Compact, se acercó a la poesía en Memoria (Mémoire, 1977) y Ópera bufa (Opéra-bouffe), donde el tema de la muerte individual, prueba de lo absurdo de la condición humana, desemboca en el de la muerte del lenguaje, colmo y conclusión del fracaso de la civilización contemporánea.

Denis Roche, al evocar en su novela Loba baja "los contactos enloquecidos e inteligentes con la Lengua-Muerte", ${ }^{56}$ los que vive el hombre de nuestro tiempo, es quien se dedica a la empresa de destrucción más radical en el campo poético. ${ }^{57}$ Obsesionado por la muerte, sobre todo en Le mécrit (1973) - palabra que sugiere a la vez "lo mal escrito y el desprecio (le mépris) hacia el lenguaje- Denis Roche se declara "sepultero de la poesía" y proclama el fin de "los poietas" ("les pohètes"), a quienes pretende detestar. Según él, el poema debe excluir ya toda vibración poética para transformarse en obra científica. A la "antinovela" y al "antiteatro", corresponde pues una "antipoesía": para Denis Roche, "la poesía es inadmisible, y además no existe".

Esa actitud suscitó reacciones contradictorias, ya que a los otros poetas les dejaba tres soluciones: insultarlo a su vez, fingir ignorarlo o

54 Desde 1950 ha publicado: Le grand recueil, 1962; Lyres, 1962; Pièces, 1962; Pour un Malherbe, 1965; Tome premier, 1965; Le savon, 1967; L'atelier contemporain, 1977; Comment une figure de paroles et pourqoui, 1977.

${ }^{55}$ Bruno VERCIER y Jacques LECARME, La littérature en France depuis 1968. París, Bordas, p. 202.

56 Denis Roche, Louve basse. París, Le Seuil, 1976, p. 13.

${ }^{57}$ Eros énergumène, 1968; Trois pourrissements poétiques; Les idées centésimales de Miss Elanize. 
asumir la mala conciencia que él despertó. La poesía, en cierta manera expulsada del paraíso, ya no pudo ser como antes.

La forma extrema de la disolución del lenguaje es la forma pulverizada, cultivada en los setentas por los poetas llamados minimalistas (André du Bouchet, ${ }^{58}$ Jean Daive, ${ }^{59}$ Alain Borer ${ }^{60}$ ), porque reducen al mínimo el material poético, presentado en estado bruto, con blancos y lagunas. Es un lenguaje descontrolado, tendido como un puente por encima de la nada: la tendencia moderna al aforismo y al fragmento se agota en el telegrama: "el poema ya no es más que la fugaz sugerencia de un poema que no está ni escrito ni por escribir". ${ }^{61}$ Bernard Noël ${ }^{62}$ inscribe palabras abandonadas en una página casi completamente blanca, palabras rodeadas de silencio.

Jean-Claude Grosjean desorganiza la sintaxis, e incluso las palabras, tomando como modelos tecnológicos la máquina de escribir y la informática: Poésie 1, Grappes, Poésie 2, etcétera; Christian Prigent (Power/ Podwer) continúa la experiencia formalista de Tel Quel recogiendo también la lección de Raymond Queneau en su práctica de la broma sobre el lenguaje. Michel Vachey, ${ }^{63}$ quien desapareciera en 1987, es un virtuoso de la tipografía y de los aspectos plásticos de la poesía: señala su relación con la pintura y el grafismo, mezcla los géneros como lo hicieron Michel Butor y Denis Roche. Vachey fundó el grupo Textruction, cuyo nombre (en el que se oyen a la vez Texte, texto, y destruction, destrucción) es ya todo un programa.

\section{Los francotiradores del Oulipo}

Entre los principales "inventores" de la literatura francesa en los últimos cuarenta años, es justo mencionar aparte un grupo de importancia menor, pero cuyos intentos contribuyen de manera significativa a derrotar los bastiones de la literatura.

Se autonombró Oulipo, Ouvroir de Littérature Potentielle (Taller de Literatura Potencial) a partir de un término, ouvroir, que designaba en

58 Airs (1951), Sans couvercle (1953), Dans la chaleur vacante (Prix des Critiques, 1961), Qui n'est pas tourné vers nous (1972), Ici en deux (1986).

${ }^{59}$ Décimale blanche, Le jeu des séries scéniques, 1 , 2, de la série non aperçue, Imaginary Who pour $B$. $N$.

${ }^{60}$ Venusberg, Le métier à citer.

61 Alain BOSQUET, "La poésie française contemporaine, 1960-1990", en Poésie aujourd'hui. París, Ministère des Affaires Étrangères, 1992, p. 18.

${ }^{62}$ Extraits du corps, L'été langue morte, La chute d'Icare, La chute des temps (1983).

${ }^{63}$ Scène d'Ob, 1970; Coulurelligne, Caviardages, 1971; Toil, 1975. 
la Edad Media y el siglo XVI un lugar de trabajo en común: aqui la palabra importa como idea de creación colectiva. Fundaron el Oulipo Raymond Queneau (cuya obra es una de las más interesantes, divertidas e innovadoras del siglo Xx), Albert-Marie Schmidt (erudito especialista de la poesía renacentista), los novelistas Jacques Bens ${ }^{64}$ y Georges Perec, y los matemáticos Claude Berge y François Le Lionnais. En el grupo aparecen también representantes del "Colegio de Patafísica" (Noël Arnaud, Latis), poetas y escritores (como Lescure, Duchâteau y Queval), corresponsales extranjeros (Italo Calvino, Stanley Chapman, Ross Chambers). Según sus propias palabras, Raymond Queneau quería promover "preparaciones e investigaciones sobre posibilidades poéticas del lenguaje, diferentes de las que existen actualmente": la idea fundamental es la de creación colectiva a partir de limitaciones o coerciones (contraintes) aceptadas libremente y de común acuerdo por el grupo.

El Oulipo remite a veces al surrealismo (en el que Raymond Queneau participara al principio de su carrera), por su carácter de creación colectiva -que evoca el "cadáver exquisito"- y por el aspecto juguetón que aquí adquiere la creación literaria. Pero al desechar el azar y el automatismo psíquico, Oulipo rechaza el surrealismo: sus antecesores reconocidos son más bien Stéphane Mallarmé y Paul Valéry, los primeros "manipuladores" del lenguaje; Oulipo defiende además el lugar del autor, cuyos derechos son negados, como lo hemos visto, por la vanguardia estructuralista. ${ }^{65} \mathrm{~A}$ contracorriente del estructuralismo y de las ciencias humanas, reafirma una vocación científica, pero fundánd ose en las matemáticas, ${ }^{66}$ o las ciencias biológicas y naturales, como el burlesco Cantatrix sopranica L. et autres scientifiques, de Georges Perec.

Perec quiso recorrer toda la literatura de su tiempo sin tener la impresión de volver atrás ni de volver a pisar sus propias huellas: "escribir todo lo que al hombre de hoy le es posible escribir". ${ }^{67}$ Esta ambición lo llevó, sin prescindir nunca del espíritu o de estructuras

${ }^{64}$ Poeta y novelista, nacido en 1931: Valentin (1958), Rouge grenade (1976).

${ }^{65}$ Para saber más sobre el Oulipo, se puede consultar el texto fundador de Raymond Queneau (Bâtons, chiffres, lettres, 1974), los Dossiers del Colegio de Patafísica (núm. 17), el libro de Paul Fournel: Clefs pour la littérature potentielle (1972), el colectivo La littérature potentielle (1973) y especialmente Oulipo. 1960-1963, una retrospectiva de Jacques Bens publicada por Christian Bourgois, que presenta las reseñas de las cuarenta primeras sesiones de trabajo del gnupo.

${ }^{66}$ Cabe mencionar que el propio Queneau escribió un libro de matemáticas modernas, Bords, 1963.

${ }^{67}$ Georges Perec, Penser/Classer. París, Hachette, 1985, p. 9. 
"oulipianas", a agotar en una perspectiva a la vez sistemática y lúdica, todas las posibilidades del lenguaje literario, desde la observación de lo cotidiano (Las cosas, 1965) hasta la construcción de una gran novela cíclica (La vida, instrucciones de uso, 1969), pasan do por la autobiografía ( $W$ ou le souvenir d'enfance, 1975; La boutique obscure, 1973) y sobre todo el juego lingüístico, trascendido aquí por el arte y la capacidad imaginativa de un prodigioso escritor: en el caso de $L a$ desaparición (La disparition, 1969), el título alude no sólo a la desaparición de un personaje, sino a la de la letra "e", completamente ausente de un libro de más de trescientas páginas. En Les revenentes (1972), Perec invirtió la coerción de manera particularmente lúdica, al escribir un libro donde todas las palabras presentan una "e", a expensas de una ortografía fantasiosa. ${ }^{68}$

El Oulipo se dedica a manipulaciones elementales inspiradas en fórmulas algorítmicas que pretenden revelar estructuras nuevas en la literatura, pero fundamentalmente basadas en la variación. Por ejemplo, "el método $\mathrm{S}+7$ " consiste en cambiar todos los sustantivos (dejando verbos y adjetivos por el séptimo sustantivo siguiente en el diccionario). Sus extensiones serán el método $\mathrm{V}+8$ (cambiar los verbos, dejando sustantivos y adjetivos, por el octavo verbo), etcétera. A partir de un texto de prestigio, como el principio de En busca del tiempo perdido, de Proust, se crea un texto nuevo $-y$, acotan con seriedad los integrantes del Oulipo, diferente, según el diccionario que se utiliza. Con un diccionario franco-alemán, el inicio del Génesis queda así transformado:

A la ligne, le chagrin créa le complément, mais le complément était informe et vide, les galettes couvraient le rafraîchissement et la balustrade du chagrin se mouvait au-dessous des suppressions. Et le chagrin dit Que l'ascenseur soit, et l'ascenseur fut. Et le chagrin dit que l'ascenseur était bon, et le chagrin séparait l'ascenseur des galettes à proximité, et il y eut un laxatif, et il y eut une lassitude. Ce fut la première danse.

La fabricación de "un cuento a voluntad suya" ("un conte à votre façon") se inspira en el juego de la oca y permite al lector elegir el orden y la naturaleza de los acontecimientos del cuento. Hay que elaborar un tablero cuyas casillas contienen las oraciones de un relato. Después de leer la oración, el lector encuentra una pregunta: si quiere que el

${ }^{68}$ Le Magazine Littéraire (núm. 316 , diciembre, 1993) dedicó un importante dossier a Georges Perec. 
personaje se case, que pase a la casilla 13; si quiere saber lo que le sucedió a la hermana, repórtese a la casilla 20, etcétera.

Las muertes de Raymond Queneau (1976) y Georges Perec (1983) privaron al Oulipo de sus verdaderos creadores; sin embargo, el Taller sigue funcionando, y los interesantes animadores hoy en día son Paul Fournel, su secretario general, y Jacques Jouet, ${ }^{69}$ quienes se dedican especialmente al género del cuento.

En 1981, tres integrantes del Oulipo fundaron con cinco especialistas en computación el grupo Alamo para experimentar a la creación colectiva con computadoras, mientras el Oulipo siempre se negó a introducir esas máquinas. Escriben textos, poemas, relatos, a veces desde la terminal hogareña, entrelazados y "tratados" por una computadora. ${ }^{70}$

\section{Consecuencias del Holocausto}

El paulatino desvanecimiento del autor, iniciado en la "nueva novela", se continuó en la "nueva crítica". Al examinar las obras literarias, ésta rechazó las explicaciones por la personalidad o la biografía del escritor y pretendió referirse al puro funcionamiento del texto, independientemente del productor de dicho texto. ${ }^{11} \mathrm{El}$ escritor, como autor dramático, dejó también los escenarios e incluso, como único responsable de la creación literaria, desapareció de la escritura misma, alcanzándose un punto extremo (de non retour) en los experimentos de redacción por medio de las computadoras. Una polémica opuso el grupo Alamo al poeta y crítico Henri Meschonnic, quien negaba el estatuto de poesía a los textos compuestos en computadora, y recalcó los límites de semejante deshumanización. Pero el gran problema que plantean estos experimentos no es tanto el de la desaparición del autor (¿quién es verdaderamente

69 Jacques Jouet, Le bestiaire inconstant (Ramsay), L'éclipse (Ramsay), Romillats (Ramsay), Des ans et des ânes (Ramsay, 1988).

70 De marzo a julio de 1985, se llevó a cabo la experiencia "Les immatériaux" ("Los inmateriales") en el Centro Georges Pompidou, con la participación de unos treinta escritores, científicos, ingenieros, artistas, lingũistas, a partir de una lista de cincuenta palabras. Esta prueba, realizada en microcomputadoras M 20 y M 24 de Olivetti prestadas por la fábrica, fue recogida en un enorme volumen publicado en 1986 por el Centro Beaubourg: Les immatériaux, épreuves d'écriture.

7 Lo ilustra una anécdota: en un coloquio de Cerisy-la-Salle sobre "los caminos actuales de la crítica", alguien interrumpió a Jean Ricardou para preguntarle, "pero de una vez por todas, dígame, señor, ¿en dónde deja usted al autor?”; Ricardou le contestó: “el autor me importa un comino, fuera del hecho de saber quién cobra los derechos". 
el autor del texto?, ¿cuál de tantos participantes?, ¿será más bien la computadora?), sino la desaparición de la escritura. La verdadera pregunta es, en efecto: lo que produce la computadora, ies en realidad poesía? ¿Si desapareció la escritura, eso es todavía literatura? Y también: ¿dónde está el texto? ¿En los misteriosos circuitos integrados de las máquinas? En el caso más perturbador todavía de la comunicación electrónica y del minitel, cuando escribo un poema a varias voces a través de la mensajería a distancia, con otros "scriptores" situados en ciudades o en países distintos, el carácter "inmaterial" del texto llega a su límite, al mismo tiempo que prolonga paradójicamente las probabilidades de sobrevivencia de dicho poema (puedo romper el monitor sin afectar al texto). La desaparición del sujeto coincide aquí con la desaparición de la escritura, incluso de aquella escritura que inventaron los sumerios en el cuarto milenio antes de Cristo.

Las imágenes de basura y podredumbre, que alimentan metafóricamente la creación literaria contemporánea, adquieren así un profundo valor simbólico. Esa literatura refleja un mundo descompuesto por la crisis de valores del siglo XX, que se inició con la Primera Guerra Mundial y que después de Paul Valéry, E. M. Cioran analizó en su Breviario de podredumbre (Précis de décomposition), publicado en 1949.

"Dios ha muerto": ya no hay fe, ni en la literatura ni en el personaje de novela, ni siquiera en el lenguaje -y es lo que autoriza el despliegue del recelo. Al empezar, el escritor reconoce, como Maurice Roche, No voy bien, pero tengo que ir, ${ }^{72}$ o se pregunta, como Beckett: "¿A Ahora adónde? ¿Ahora cuándo? ¿Ahora quién? Sin preguntármelo. Decir yo. Sin pensarlo. Decir que son preguntas, hipótesis. Ir hacia adelante, decir que eso es ir, decir que eso es adelante..."73

Se extinguió la creencia de que el hombre dominaba el lenguaje; por el contrario, el lenguaje - se teme- podría dominar al hombre, atravesándolo a pesar suyo. El lenguaje participa asi de la podredumbre general de los valores, como en la obra de Maurice Roche: "la escritura se convierte en terreno contagioso que propaga sin resistencia alguna las infecciones del lenguaje". ${ }^{74}$

Esa excelente definición de Jean-Louis Bouttes puede aplicarse tanto a Codex (1974) como a buena parte de la literatura contemporánea. En su afán por destruir el protocolo de la escritura, Maurice Roche designa el

\footnotetext{
${ }^{72}$ Maurice RoCHE, Je ne vais pas bien, mais il faut que j'y aille. Paris, Le Seuil, 1987.

${ }^{73}$ S. BECKETT, L'innommable. Paris, Minuit, 1956, p. 7.

${ }^{74}$ Jean-Louis BouTtes, “Codex”, en La Quinzaine Littéraire. París, enero, 1975.
} 
lenguaje como algo enfermizo, infeccioso, pero asimila el ritual de la literatura, cuyo objetivo es "curar" el lenguaje, a la medicina. Codex (en español, códice) se puede leer Code X (código equis, un código incógnito o un código que nos falta inventar), 0 , con una equis más grande, un código (el lenguaje, el código por antonomasia) tachado por la cruz que lo aniquila. El título remite también a los códices mayas, cuyas prescripciones médicas, junto con las de papiros egipcios, montadas en el texto, invaden el espacio de ese extraño libro que se refiere explícita y nostálgicamente a los orígenes de la escritura.

En Loba baja ${ }^{75}$ la larga, alucinante podredumbre del cuerpo del autor que concluye la novela, simboliza la podredumbre. De hecho, la LenguaMuerte es el principal personaje de Denis Roche, quien parece haber llevado a su etapa extrema el procedimiento de Beckett en Malone muere.

La literatura francesa de la segunda mitad del siglo Xx, la del fin de milenio, se presenta así como la de un fin de la literatura. Denis Roche: "la littérature est périmée depuis longtemps et l'écrivain lui-même est un préjugé du passé". ${ }^{76}$ Italo Calvino: "Samuel Beckett ha obtenido los resultados más extraordinarios reduciendo al mínimo elementos visuales y lenguaje, como en un mundo después del fin del mundo". ${ }^{77}$

El milenarismo engendra casi la misma angustia hoy día que en la Edad Media; ${ }^{78}$ como en los albores del año 1000 , el acercamiento al año

${ }^{75}$ Louve basse. Ce n'est pas le mot qui fait la guerre, c'est la mort. Paris, Le Seuil, 1976.

76 Ibid., p. 132.

${ }^{77}$ Italo Calvino, Seis propuestas para el próximo milenio. Trad. de Aurora Bernárdez. Madrid, Siruela, 1989, p. 110.

78 Uno de los pocos documentos sobre la época del año 1000 son las Historias de Radulfus Glaber (985-1047), monje de Saint-Germain d'Auxerre, que viajó a los monasterios de Saint-Jean de Moutiers (1005-1010), de Saint-Bénigne y de Cluny, donde escribió de 1030 a 1050 ese testimonio de la época que son los cinco libros de sus Historias. Cf. Raoul GLABER, Les cinq livres de ses Histoires. Ed. de M. Brou. París, 1886 (Textes pour servir à l'étude et à l'enseignement de l'histoire); Radulfus GLABER, Opera. Oxford, Universidad de Oxford, 1989 (Oxford Medieval Texts); Richer, Histoire de France (888-995) [Historiarum libri]. Ed. y trad. de Robert Latouche. París, 1937 (Les classiques de l'histoire de France. Moyen Age, 2), pp. 954-995; L'an 1000. Recueil de chroniques de R. Glaber et autres. Ed. y trad. de Edmond Pognon. París, 1947; L'an 1000. Formation de la légende de l'an 1000. L'état de la France en 1050. Ed. de J. Roy. París, 1885; Georges DUBY, L'an 1000. París, Gallimard/Julliard, 1980 (Archives); Henri FocILloN, $L$ 'an 1000. Armand Colin, 1952; E. ORTIGUES, "Raoul Glaber et 1'historiographie clunisienne", en Studii Medievali, IIIe série, núm. 26/2, 1985, pp.535-572; E. GEBHART, "L'état d'âme d'un moine de l'an 1000. Moine et pape: essai de psychologie historique", en La Revue des Deux Mondes. París, septiembre, 1891, p. 600 y ss. 
2000 invita a muchos espíritus pusilánimes a considerar la civilización de hoy como el final de una historia; hace temer que estemos viviendo el fin de un mundo. Por el amarillismo de su título, El final de la historia y el último hombre, ${ }^{79}$ se transformó en un verdadero best-seller intelectual de los últimos años; provocó apasionadas reacciones alrededor de las tesis de Fukuyama, con motivo de una entrevista publicada a principios de 1992 en la revista Le Point. ${ }^{80}$ La literatura contemporánea se articula, pues, entre la angustia del absurdo (en los años cuarentas y cincuentas) y la angustia del milenarismo (en los ochentas y noventas). Pese al humanismo irreprimible de Homero Aridjis, y aun sin implicaciones ecologistas, es legítimo considerar no sólo al poeta sino al escritor $y$ al hombre en general, como una especie en peligro de extinción. ${ }^{81}$

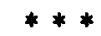

En todo caso, parece que no se puede ir más lejos en una dirección que pone en peligro la noción misma de literatura. Sin embargo, la literatura, como la vida, sigue adelante: persiste la demanda de un público que desea literatura fresca. Las publicaciones literarias, que sólo representaban $14 \%$ de la producción en 1900 , ocuparon $35 \%$ de la producción total en los cincuentas; además, de los años cincuentas a los sesentas el número anual de publicaciones en Francia pasó de 10000 a 20000 títulos para rebasar los 26000 en los ochentas, doblando asi los 13000 que caracterizaban los primeros años del siglo. ${ }^{82} \mathrm{~A}$ medida que se acerca el año 2000, el transmilenarismo permite acomodar la vista y constatar que no pasa nada: "-Curieuse fin de siècle". "- Vous voulez dire curieux commencement du suivant?"83

Incluso hay tiempo para escribir y leer obras menos proféticas pero más respirables.

${ }^{79}$ Francis Fukuyama, El final de la historia y el último hombre (1991), publicado en forma simultánea en Estados Unidos, Francia, Gran Bretaña y Alemania. Francis Fukuyama despertó la curiosidad internacional en 1989 , por un artículo publicado en la revista norteamericana National Interest.

${ }^{80}$ Le Point. Paris, 25 de enero, 1992.

${ }^{81}$ Cf. Homero ARIDIS, El poeta en peligro de extinción. México, El Tucán de Virginia, 1992, pp. 40-42.

${ }^{82} C f$. Françoise GERBOD y Paul GERBOD, Introduction à la vie littéraire du XX siècle. París, Bordas, 1986, pp. 69-73.

${ }^{83}$ Philippe SOLLERS, Le secret. París, Gallimard, 1992, p. 250. 
Las literaturas autodestructoras o apocalipticas son generalmente difíciles, y su acceso está reservado a una elite intelectual: se aprecian a condición de compartir cierta cultura con el autor. Por otra parte, el lector mejor preparado o mejor intencionado llega a aburrirse frente a la descripción demasiadas veces repetida de la sombra de una pantalla en el techo del cuarto de Alain Robbe-Grillet (En el laberinto), frente a esas monótonas sucesiones de textos despedazados, de frases o palabras en trizas, o a las reseñas computarizadas de Olivetti, o frente a las reiteradas demostraciones del fracaso de la literatura. El abandono paulatino de la literatura experimental por parte de los más jóvenes escritores y la preferencia del público por obras más tradicionales, revelan un amplio movimiento de rechazo en contra de la llamada "nueva" literatura, que ya parece demasiado intelectual y algo obsoleta. Frente a la incomprensión de las mayorías, esa literatura experimental, que organizó su propio funeral, terminó por aniquilarse. Incluso en el campo de la crítica, el lingüista Georges Mounin ya expresó en los años setentas, en La literatura y sus tecnocracias, ${ }^{84}$ una protesta de alto nivel en contra de los excesos intelectualistas de la modernidad.

Al lado de una literatura experimental ensalzada por el esnobismo intelectual, la mayor parte de la producción literaria contemporánea continúa varias éticas o estéticas tradicionales. Por lo tanto, después de este rápido sobrevuelo de una literatura absorta en cuestiones formales, queda por examinar, a merodeo tendido, una literatura en la que los temas importan más que la forma: existen también quienes tienen algo que decir y se conforman con ser buenos escritores.

\section{Los géneros recobrados}

Desde 1950, a la literatura francesa la caracteriza no sólo el deseo de dejar atrás las formas del pasado, sino también las grandes obras de escritores ya consagrados antes o inmediatamente después de la Segunda Guerra Mundial.

Paul Claudel, miembro de la Academia Francesa desde 1946, retirado en su propiedad del Dauphiné, dedica sus últimos años (hasta 1955) al comentario lírico de textos bíblicos: El apocalipsis (1952) no es más que la continuación de Présence et prophétie (1946). Albert Camus (Premio

${ }^{84}$ Georges MoUnIN, La littérature et ses technocraties. París, Casterman, 1978. 
Nobel 1957) muere accidentalmente en 1960, en pleno periodo creativo, pero la publicación póstuma de sus Cuadernos (Carnets, 1962-1964) prolonga su influencia. Blaise Cendrars y L. F. Céline vivieron y escribieron hasta 1961; André Breton, hasta 1966; Jules Romains, Jean Giono y François Mauriac (Premio Nobel 1952), hasta 1970; Henri de Montherlant, hasta 1972; los poetas Patrice de La Tour du Pin y SaintJohn Perse (Premio Nobel 1960), hasta 1975; Pierre Jean Jouve y André Malraux, hasta 1976; Jean-Paul Sartre (Premio Nobel 1964), hasta 1980; Louis Aragon, hasta 1982; Henri Michaux, hasta 1984; René Char, hasta 1989; Michel Leiris, hasta 1990. Sus obras de madurez o de la vejez, casi siempre relevantes, configuran tanto el quehacer literario de la segunda mitad del siglo XX, como los brotes o las obras primeras de escritores más impacientes y menos seguros de sus medios de expresión.

Ciertos autores prosiguen con esmero su obra anterior (Julien Green, ${ }^{85}$ François Mauriac); otros, que en su tiempo habían sido verdaderos fundadores, producen obras maestras poco advertidas (Céline, Aragon, Queneau, Char); algunos cambian tanto la dirección de su obra, que los años cincuentas parecen señalar nuevos inicios: las últimas novelas de Jean Giono forman un conjunto impresionante tanto en cantidad como en calidad, que obliga a los historiadores de la literatura a revisar su clasificación de Giono como escritor regionalista. Dueño de una nueva juventud, el novelista meridional rompe los esquemas en 1951 con Les grands chemins, Le hussard sur le toit, y también con cada una de sus obras ulteriores, ${ }^{86}$ hasta las póstumas: Les récits de la demi-brigade (1972) y Le déserteur (1973).

Cabe mencionar también la evolución de grandes familias de escrituras (el surrealismo, el existencialismo, la escritura marxista, la católica) y la permanencia de géneros tradicionales como la novela histórica, psicológica, la poesía lírica y la balada, la novela policiaca y, de manera notable, el desarrollo de un género, la autobiografía, dotado al parecer de la capacidad de rescatar otros géneros en vías de extinción.

\section{Existencialismo}

El existencialismo marcó profundamente la posguerra en Francia, pero poco después de los años cincuentas fue rápidamente superado por las

${ }^{85}$ Hasta un reciente libro de cuentos: Histoires de vertige, 1984.

${ }^{86}$ Le chemin de Pologne (1953), Le bonheur fou (1957), Angelo (1958), Domitien (1959), Oppede (1960), Deux cavaliers de l'orage (1965), Ennemonde (1968), L'iris de Suse (1970). 
nuevas vanguardias: Beckett, Ionesco y demás autores de la "nueva novela" consiguieron expresar mejor que Sartre o Camus lo absurdo de la condición humana y la angustia contemporánea. Por otra parte, Sartre y Camus dedicaron más energía a su obra filosófica, o de crítica literaria y política, que a la literatura propiamente dicha. Sin embargo, el libro de cuentos de Camus ( $L$ 'exil et le royaume, 1957 ) y su última novela ( $L a$ chute, 1958), son dos obras maestras, de rango similar a Las palabras de Sartre (Les mots, 1965), la culminación de su arte literario: uno de los libros más bellos de la literatura francesa.

Además de sus ensayos (filosóficos, políticos y sociológicos), Simone de Beauvoir publicó una gran novela (Les mandarins, 1954) y una larga autobiografía. ${ }^{87} \mathrm{Su}$ obra es a la vez testimonio sobre la vida de los intelectuales contemporáneos y documento humano sobre las relaciones del sujeto con el compromiso y los paradigmas.

En la órbita existencialista, la novelista más destacada es Violette Leduc, muy apreciada por Sartre y Simone de Beauvoir. La bâtarde (1964) expresa, a través del relato autobiográfico, la angustia y la soledad contemporáneas. La femme au petit renard (1966), desgarrador soliloquio de una solterona abandonada, simboliza la indigencia y el naufragio afectivo. Violette Leduc prosiguió esta empresa autobiográfica con La folie en tête y, más recientemente, con La chasse à l'amour (1974).

\section{Surrealismo}

Maurice Nadeau advertía en 1974 que "en el marasmo de escrituras que circulan hoy día", son los escritores surrealistas los que curiosamente, en lugar de asociarse a la iconoclastia contemporánea, expresan por el contrario un regreso a la literatura.

Aragon, que había tomado ya sus distancias con el surrealismo, prosiguió su obra de novelista con la serie Los comunistas, terminada en 1951. La Semana Santa (La Semaine Sainte, 1958), basada de la vida de Napoleón I, hacía el intento de un nuevo tipo de novela histórica, donde los personajes de 1815 comparecen ante la sensibilidad moderna. En un verdadero hervidero inventivo, Aragon parecía proseguir un proyecto humanista, aplicando la interrogación ¿qué es realmente el hombre? tanto a la crítica literaria (Lumière de Stendhal, 1954) como a sí mismo,

${ }^{87}$ Mémoires d'une jeune fille rangée (1958), La force de l'âge (1960), La force des choses (1963), Une mort très douce (1965). 
por medio de la poesía lírica ${ }^{88}$ y sobre todo del largo poema autobiográfico que es Le roman inachevé, 1956. En la década de los sesentas, Blanche ou l'oubli ilustra una nueva manera (1967). En La mise à mort (1965), Aragon utiliza con moderación ciertas innovaciones de la literatura en la técnica del relato, logrando una de sus obras más conmovedoras. Théâtre/ Roman, en 1974, sí opera el regreso a la literatura, y esto a pesar de la reedición de El libertinaje (1978), texto escrito a los veintiséis años, donde Aragon ya intentaba "destruir la novela por sus propios medios". ${ }^{89}$ Le mentir vrai (1981), cuyo título parece una definición moderna de la literatura, incluye también varias reediciones de textos más antiguos.

Pero con Aragon, el surrealismo se ve finalmente rebasado por el humanismo y el marxismo. ${ }^{90} \mathrm{El}$ surrealismo propiamente dicho no conserva, después de los años cincuentas, el mismo vigor de antes. Maurice Nadeau, historiador del movimiento, propone una explicación convincente: el surrealismo ofrecía al hombre un proyecto de renovación total de su visión del mundo y del arte, en un contexto dominado todavía por el positivismo y el chauvinismo; la rebeldía tenía entonces sus raíces en el desengaño que experimentó la civilización occidental después de las matanzas de 1914. Los surrealistas habían anunciado y practicado la filosofía del absurdo y el compromiso existencialista hasta la locura (Artaud), el suicidio (René Crevel), el militantismo (Eluard, Aragon). Habían ensayado nuevas formas de creación para escapar a la dictadura del racionalismo; habian defendido la psicología freudiana cuando ésta se desconocía aún en Francia. Después de 1950, el papel histórico del surrealismo está terminado, aunque sus reivindicaciones sigan de pie. Con Camus y Sartre, con Beckett y la liberación de las formas literarias, con la generalización del psicoanálisis y su reformulación a la luz de la lingüística, llevada a cabo por Jacques Lacan, la actividad surrealista ha perdido toda fuerza subversiva.

Consciente de su alejamiento de la vanguardia, André Breton tuvo la inteligencia de desplazar la lucha e inclinó el movimiento, explotando así otra riqueza potencial del primer surrealismo, hacia la exploración de

\footnotetext{
${ }^{88}$ Les yeux et la mémoire (1954), Elsa (1959), Le fou d'Elsa. Il n'est Paris que d'Elsa (1964).

${ }^{89}$ Maurice NADEAU, "Beaucoup plus tard", en Histoire du surrealisme. París, Le Seuil, 1970 (Points), pp. 187-189.

90 Mencionemos como representantes de la escritura marxista a Roger Garaudy y a André Stil (Le premier choc, 1951-1954; La question du bonheur est posée, 1956-1960; Viens danser Violette, 1964).
} 
las fuentes secretas de la actividad poética, de la tradición alquímica, hacia el esoterismo. Para Nadeau, esa actitud constituye a la vez la confesión de una derrota y un triunfo nuevo: el surrealismo es ahora el refugio de lo irracional y de lo mágico, el detonador que podría salvar un mundo osificado en un nuevo cientismo y en sus tecnocracias - un mundo que ha demostrado cuántas fuerzas autodestructivas es capaz de generar. ${ }^{91}$ A pesar de la dispersión progresiva del grupo que ha perdido sus líderes, el surrealismo permanece como estado anímico, como reserva de ideal para cualquier contestación social, lo que explica su breve renacimiento en la explosión de mayo $1968 .^{92}$

Varios novelistas aparecen como hijos del surrealismo: Pierre Klossowski, "romancier du phantasme", ${ }^{93}$ recoge la herencia de Bataille, de Artaud y de Michel Leiris; más allá, de Nietzsche y del marqués de Sade. Klossowski profundiza en su obra algunos temas obsesivos que resumió Juan García Ponce en el título de su libro Teología y pornografía. Pierre Klossowski en su obra: una descripción. Julien Gracq continúa otro aspecto del surrealismo: su dimensión onírica, heredada del romanticismo, especialmente del alemán. En una prosa de perfección estilística, Gracq comunica al lector sensaciones y atmósferas donde el sujeto se enfrenta al paisaje, o se diluye en él: la Bretaña en Au château $d^{\prime} A r g o l$, el mar en Le rivage des Syrtes (1951), el bosque de las regiones fronterizas con Alemania en Un balcon en forêt (1958), varios paisajes en los cuentos de La presqu'île (1970). André Pieyre de Mandiargues, poeta (L'âge de craie, 1964), cuentista (Soleil des loups, 1951; La porte dévergondée, 1965) y novelista, combina la evocación minuciosa de lugares reales (Italia en Marbre, 1953 y en Le Lis de mer, 1956; Barcelona en La marge, 1967) en un ambiente extraño que propicia excesos en la conducta de sus personajes. Pieyre de Mandiargues aparece como el heredero más auténtico del surrealismo: su arte es un realismo que nos invita, frente a conductas absurdas, ilógicas, inquietantes, a descubrir otra realidad, la surrealidad como verdad misma de los seres.

\footnotetext{
91 Jean-Louis Bédouin escribió una continuación de la historia del surrealismo: Vingt ans de surréalisme, 1939-1959 (1961).

92 Hoy día, la investigación más rigurosa sobre el surrealismo como movimiento y como mentalidad es la que lleva a cabo Jacqueline CHÉNIEUX GENDRON, Le surréalisme et le roman. Laussanne, L'Age d'Homme, 1983; Le surréalisme. París, P. U. F., 1984; Poétiques surréalistes. París, P. U. F., en prensa.

${ }^{93}$ Novelista del fantasma, pero en el sentido clínico de esta palabra en el psicoanálisis. La révocation de l'Édit de Nantes (1954), Le soufleur (1960), Le Baphomet (1965).
} 
Entre surrealismo y existencialismo, o cabalgando libremente sobre los dos, surge Boris Vian. Su obra, publicada entre 1946 y 1959 , reeditada después de la muerte del autor, tuvo gran éxito y ejerció una profunda influencia sobre los escritores de los años sesentas. Se reveló como precursora tanto del nuevo teatro (L'équarissage pour tous, 1947; Les bâtisseurs d'empire, 1959; Le goûter des généraux, publicado en 1964) como de la nueva novela ( $L$ 'écume des jours, 1947; L'herbe rouge, 1950; L'arrache-coeur, 1953). Músico de jazz, Boris Vian compuso melodías para sus poemas, que hacen de él el precusor de la balada moderna. Fue el espiritu mismo de la vida del barrio de Saint-Germain des Prés después de la guerra, lugar predilecto de los intelectuales de la época, en el ambiente existencialista que describió Simone de Beauvoir en La force des choses (1963). Por su anticonformismo, su violencia, su genio inventivo, Boris Vian sigue siendo portavoz perdurable de la juventud.

\section{Poesía contemporánea}

Según una encuesta reciente, el número de poetas en Francia se multiplicó después de la Segunda Guerra Mundial, hasta rebasar 2000 . Jacques Bens explica este fenómeno tanto por la democratización de la expresión personal - cada quien tiene algo que decir y siente el derecho de decirlo-como por la automatización de las formas poéticas - ya no hay reglas rigurosas y todos los modos de expresarse se valen. ${ }^{94}$ Paralelamente, la poesía perdió sus lectores, es decir, el prestigio que tenía para un amplio público en tiempos de Víctor Hugo: "más y más gente escribe esta cosa que nadie lee". 95

En efecto, la poesia fue marginada por la necesidad de renovación y la consiguiente complejidad que adquirió para distinguirse de los otros modos de expresión literaria, y también de la poesía anterior: muchas veces hermética 0 abstrusa, la poesia francesa contemporánea aparece como el divertimiento gratuito de cenáculos cerrados y recelosos.

En medio de la proliferación de revistas poéticas y tirajes confidenciales, se distingue sin embargo una sólida producción que recoge la tradición lírica. La poesía contemporánea se funda en la obra de autores que pertenecen al periodo anterior a 1950 . Sus verdaderos renovadores

\footnotetext{
${ }^{94} C$. Jacques BENS, “Les poètes en France”, en Universalia 1981. París, Encyclopedia Universalis, 1981, pp. 447-450.

95 "Il y a de plus en plus de gens pour écrire cette chose que persone ne lit". (G. Mounin, apud Jacques BENS, idem.)
} 
se llaman Saint-John Perse, ${ }^{96}$ Jules Supervielle, ${ }^{97}$ Paul Claudel, Paul Eluard, ${ }^{98}$ Francis Ponge, Henri Michaux, Pierre-Jean Jouve, Pierre Emmanuel y sobre todo René Char ${ }^{99}$ Frente a esas voces, que sólo continúan en este periodo una tarea iniciada en los años veintes o antes, algunos jóvenes ofrecen versiones más pálidas de lo que podría ser una poesía contemporánea.

Los años cincuentas marcan una doble ruptura: el agotamiento del surrealismo y la liquidación de la poesía cívica, característica de la guerra y la Resistencia. Sin embargo, una poesía de compromiso fue continuada por los rapsodas del comunismo (en torno a la revista Les Lettres Françaises), la revista y el movimiento Change, fundados en 1968 por Jean-Pierre Faye, pretendieron cambiar la conciencia política gracias a la poesía. El compromiso se expresó también a través de la revista Action Poétique en la que participaron en los años sesentas Gérard Neveu, Jean Malrieu y Jacques Roubaud. ${ }^{100}$ Los últimos libros de Charles Dobzynsky, después de una poesía comprometida en la Resistencia y el comunismo, abordan ahora una poesía que relaciona los elementos naturales con las vibraciones del alma. ${ }^{101}$

La llamada "Escuela de Rochefort" habia reunido en 1941 jóvenes poetas originarios del Oeste de Francia, quienes en el contexto de la Ocupación afirmaron la absoluta libertad del poeta. Luc Bérimont, Jean Roussel ot, René-Guy Cadou ${ }^{102}$ y algunos más, pretenden volver a la psicología y rebelarse contra el intelectualismo parisino; después de la guerra, en medio de los avatares y malestares de la escritura, cantan la vida sencilla con amabilidad, ternura y sensualidad. Patrice Delbourg (Toboggans, 1976), Robert Sabatier, Jean Cayrol (Poésie Journal, 19771978), o Christian Bachelin ${ }^{103}$ son otros poetas de la sensibilidad, así

96 Amers (1957), Chronique (1960), Vents (1964), “Chanté par celle qui fut là" (1969).

97 Publicó todavía Naissances (1951), L'escalier (1956), Corps tragique (1959).

${ }^{98}$ Une leçon de morale (1950), Le Phénix (1951), Poésie ininterrompue II (1952) y varias obras póstumas: Derniers poèmes d'amour (1962), Le poète et son ombre (1963).

${ }^{99}$ Les matinaux (1950), Le soleil des eaux (1951), Recherche de la base et du sommet (1955), La parole en archipel (1962), Commune présence (1964), Retour amont (1966), Aromates chasseurs (1977).

${ }^{100}$ Nacido en 1932. Epsilon (1967), Mono no aware. Le sentiment des choses (1967),

Trente-et-un au cube (1973).

${ }^{101}$ L'opéra de l'espace, La table des éléments.

102 Nacido en 1920.

${ }^{103}$ Nacido en 1940. Médiéval in blues (1980), Complainte cimmérienne (1989). 
como Jacques Charpier, ${ }^{104}$ Jean Breton, Jean Orizet, ${ }^{105}$ animadores de la revista Poésie 1.

En los sesentas, se afirma una poesía exigente que explora el camino abierto por Saint-John Perse y Jules Supervielle. Ésta se niega a expresar elementos exteriores como el compromiso o la reflexión sobre el lenguaje, devolviendo así el discurso poético a su función original. Frente a los sepulteros y a las infecciones del lenguaje, Yves Bonnefoy ${ }^{106}$ construye una meditación sobre la poesía, la muerte y la resurrección de la palabra, iniciada con Du mouvement et de l'immobilité de Douve, justamente en el año significativo de 1953, grado cero de la escritura, lanzamiento de la nueva novela y descubrimiento de lo innombrable. La obra de Yves Bonnefoy, ${ }^{107}$ de cara totalmente al exterior, dedicada al mundo, floreció con Hier régnant désert (1960), Pierre écrite (1965), Dans le leurre du seuil (1977), Ce qui fut sans lumière (1987). Yves Bonnefoy es además crítico de arte y responsable desde 1981 de la cátedra de poética en el Collège de France.

Al lado de aquella vía regionalista y de esta vía laica, una tercera vía continúa la gran tradición lírica: la vía cristiana. Jean-Pierre Lemaire ${ }^{108}$ y Philippe Delaveau ${ }^{109}$ buscan una forma moderna de lirismo católico que se remonta a Paul Claudel, a través de las obras de Jean-Claude Renard, ${ }^{110}$ Jean Grosjean, ${ }^{111}$ Pierre Emmanuel, ${ }^{112}$ Patrice de La Tour du Pin $^{113}$ y Charles Le Quintrec. ${ }^{114}$

En los ochentas, la vanguardia fundada en el formalismo, la lingüística y la "nueva crítica" queda definitivamente extinguida y la poesia vuelve

104 Nacido en 1926. L'honoré du temps 1977.

105 Nacido en 1937. Vacarme du secret (1974), Poèmes 1974-1989 (1990).

106 Nacido en 1923.

${ }^{107}$ Nacido en 1923. Du mouvement et de l'immobilité de Douve (1953), Hier régnant désert (1960), Pierre écrite (1965), Dans le leurre du seuil(1977), Ce quifut sans lumière (1987).

108 Nacido en 1948. Visitations (1982).

109 Nacido en 1950. Eucharis (1989).

110 Nacido en 1922. La Terre du sacre (1966), Métamorphoses du monde, Origine et autres textes (1991).

111 Nacido en 1912. Élégies (1966); su magnífica versión francesa del Génesis ha sido prologada por J. M. Le Clézio.

112 Visage nuage (1955), Evangéliaire (1961); Chanson de décembre (1967), Sophia (1973), Tu (1978).

113 Nacido en 1911, falleció en 1975. Une somme de poésie (1950), Le second jeu (1961).

${ }^{114}$ Nacido en 1926. Les noces de la terre (Grasset), La lampe du corps (Albin Michel). 
a encontrar un neorrealismo (Jacques Réda ${ }^{115}$ ) o ese lirismo que es en palabras de Philippe Delaveau "un canto límpido, muchas veces misterioso y resplandeciente de una extraña luz"."16

Eugène Guillevic merece un lugar aparte. Aunque nació en 1907 y su primer libro (Terraqué, 1942) fue muy destacado en plena guerra, sus obras maestras pertenecen a la segunda mitad del siglo. Con una notable exigencia y una concisión extrema, que recuerdan a Char y a Ponge, parece dedicarse a un inventario del mundo, de las cosas, de los elementos de la naturaleza: Carnac, 1961; Sphère, 1963; Avec, 1966; Euclidiennes, 1967; Ville, 1969; Paroi, 1970; Inclus, 1973; Askennou/Encoches, 1975; Etier, 1979; Requis, 1983; Le Chant, 1983.

Pero las dos voces mayores son las que representan tal vez la verdadera posteridad del surrealismo: Michaux y Char. Henri Michaux, hombre dividido, desgarrado entre la creación poética y la creación gráfica, entre la paz.y el sufrimiento, confiere una dimensión más profunda a la poesía autobiográfica: en sus obras explora todas las zonas del mundo y del ser humano. Michaux es el poeta del viaje, ya sea el viaje exterior o el interior, hasta los linderos de lo que Baudelaire llamaba "los paraísos artificiales". 117

Después de la ruptura del surrealismo y del cisma de la nueva escritura, la poesia solar de René Char realiza, en el mundo de comunismo burócrata y masivo -y en los albores de la globalización, o para retomar su propia expresión, en nuestra época de "atontamiento" (enniaisement)-, la reconciliación de la palabra y el mundo. En efecto, Char, quien dedicó su última obra a hacer el elogio de una sospecha (entiéndase, la poesía), había reconquistado la esencialidad: "id a 10 esencial: ¿no tenéis necesidad de árboles jóvenes para repoblar vuestra floresta?"118

Su exigencia formal y moral, su rechazo de las palabrerías inútiles, su

${ }^{115}$ Amen (1968), Récitatif (1970), La tourne (1975), Les ruines de Paris (1977).

116 “[...] favoriser l'éclosion d'un chant limpide, souvent mystérieux, et frappé de ce fait d'une étrange lumière". (Philippe DELAVEAU, La poésie française au tournant des annés 80. París, José Corti, 1988, p. 8.)

${ }^{117}$ Misérable miracle (1956), L'infinit turbulent (1957), Connaissance par les gouffres (1961), Porteaux d'angle (1971), Face à ce qui se dérobe (1975), Moments (1973), Chemins cherchés, chemins perdus, transgressions (1981). Déplacements. Dégagements, 1985 , recoge sus últimos poemas.

118 “Allez àl'essentiel: n'avez-vous point besoin de jeunes arbres pour repeupler votre forêt?" (René CHAR, "Rougeur des matinaux", en Les matinaux. París, Gallimard, 1983 [Bibliothèque de la Pléiade], p. 330.) 
culto de la forma breve y del fragmento encuentran su sentido en una aguda conciencia de los problemas políticos (participó en la Resistencia) y lingüísticos del momento: su palabra en archipiélago ${ }^{119}$ se refiere a una concepción moderna de la poesía, donde desaparecen los géneros tradicionales. "Por qué poema pulverizado? Porque al final de su viaje hacia el Terruño, después de la oscuridad prenatal y la dureza terrestre, la finitud del poema es luz, don del ser a la vida". ${ }^{120}$

Una palabra por sí sola puede construir un poema: el poema-palabra emerge del mar del silencio, como una isla, pero misteriosas relaciones unen las palabras y construyen esa estructura que Char nombra metafóricamente archipiélago, combinación significante donde cada palabra, cada poema es un mundo con un paisaje y un ambiente específicos: la imagen del archipiélago reconcilia fragmentación y unidad. El resplandor desconcertante de sus metáforas significan una reivindicación de la Belleza que rebasa todos los esteticismos: "En nuestras tinieblas, no hay un espacio para la belleza. Todo el espacio es para la Belleza". ${ }^{21}$

\section{Autobiografía y realismo tradicional}

La gran boga del género autobiográfico, que incluso ha sido objeto de una teorización crítica que combina provechosamente psicoanálisis, sociología y poética -la de Philippe Lejeune ${ }^{122}$ caracteriza la literatura francesa moderna a tal punto que, desde 1950, "la autobiografia se ha vuelto el lugar común, la banalidad misma de la literatura comercial, sin preocupación por la paradoja (¿acaso el autor, el sujeto, como Dios mismo, no han muerto?)". ${ }^{123}$

Sin detenerse más en la boga del reportaje o "literatura de lo vivido" (littérature du vécu), que autoriza a cualquier estrella de cine o personaje público a redactar sus vivencias (directamente o por medio de negros),

${ }^{119}$ La parole en archipel (1952-1960), título que proviene de un texto particularmente bello y sorprendente: "Notre parole, en archipel, vous offre, après la douleur et le désastre, des fraises qu'elle rapporte des landes de la mort, ainsi que ses doigts chauds de les avoir cherchés". ("Quitter", en op. cit., p. 409.)

120 "Pourquoi poème pulverisé? Parce qu'au terme de son voyage vers le Pays, après l'obscurité prénatale et la dureté, la finitude du poème est lumière, apport de l'être àla vie". (R. CHAR, "La bibliothèque est en feu", en La parole en archipel, p. 378.)

121 "Dans nos ténèbres, il n'y a pas une place pour la Beauté. Toute la place est pour la Beauté". (R. CHAR, "Feuillets d'Hypnos", en Fureur et mystère [1943-1944], p. 232.)

${ }^{122}$ Le pacte autobiographique (1976), Je est un autre (1980).

${ }^{123}$ Nathalie PIÉGAY-Gros, "Michel Leiris, análisis de sí mismo, análisis del otro", en “La Jornada Semanal”, núm. 101, supl. de La Jornada. México, 19 de mayo, 1991, p. 28. 
como el presidiario Papillon, se puede afirmar que casi todos los escritores contemporáneos han intentado ilustrar un género apoyado sobre una larga tradición: la de los diarios íntimos, memorias y testimonios dirigidos a la posteridad (Montaigne, Saint-Simon, Rosseau, Amiel, Chateaubriand, etcétera). Destacaron en las últimas décadas Malraux (Antimémoires, 1967; Les chênes qu'on abat, 1971; La tête d'obsidienne y Lazare, 1974, integran el ciclo Le miroir des limbes), Raymond Aron (Mémoires. 50 ans de réflexions politiques, 1983) y Charles de Gaulle, cuyas Memorias (Mémoires de guerre, 1954-1959; Mémoires d'espoir, 1970) son indudablemente uno de los monumentos literarios del siglo.

Marcel Pagnol, aparte de algunas piezas de teatro o adaptaciones cinematográficas, ya no escribió más que su autobiografia. ${ }^{124}$ François Mauriac mezcla con acierto novela y autobiografía en su último libro, Un adolescent d'autrefois (1969). Los "nuevos novelistas" también llegan al género autobiográfico, en particular Nathalie Sarraute, Marguerite Duras $^{125}$ y Claude Mauriac con la serie Le temps immobile. Hay quien, como Genet, hace de su vida una leyenda ("mi victoria es verbal y se la debo a la suntuosidad de los términos"), quien busca la explicación de su vida en la de sus antecedentes (Marguerite Yourcenar en Archivos del norte), quien, como Julien Green, pretende descubrir por la fuerza de su sinceridad la verdad profunda de su existencia (Partir avant le jour, 1963; Mille chemins ouverts, 1964; Terre lointaine, 1966).

Pero Michel Leiris permanecerá, a todas luces, como la figura sobresaliente de este género. Aunque sea también etnólogo y poeta, el Leiris autobiógrafo es el que marca más profundamente la literatura de su tiempo. El ciclo La règle du jeu (Biffures, 1948; Fourbis, 1955; Fibrilles, 1966; Frêle bruit, 1976) y luego La cinta en el cuello de Olimpia (1981), realizan el designio planteado ya en 1939 en La edad adulta. Leiris desecha la autobiografía como empresa apologética, cuyo objetivo es reconstruir un yo con unidad preexistente que podría reflejarse en el libro, para transformar la escritura, "viaje al interior de sí mismo", ${ }^{126}$ en

${ }^{124}$ La gloire de mon père. Le château de ma mère (1957), Le temps des secrets (1960), $L$ 'eau des collines (1963).

125 En particular, con Una presa para contener el Pacifico (Un barrage contre le Pacifique, 1950), que dio la fama a su autora y cuenta recuerdos de su juventud; El dolor (La douleur, 1985) se presenta como recolección de textos de juventud que traducen la angustia de la guerra y de la ocupación alemana; El amante (1984) y El amante de la China del Norte (1991) regresan a su juventud en el Extremo Oriente.

${ }^{126}$ N. PIÉgaY-Gros, op. cit., p. 27. 
una empresa analítica y ética —“dialéctica" según Butor. 127 "Parodiando a Ricardou, quien se refería al nouveau roman, afirmaremos que lejos de ser 'la escritura de una aventura', [la obra de Leiris] se vuelve la aventura de una escritura autobiográfica y de la relación entre el sujeto y el lenguaje". ${ }^{128}$

Al margen de la autobiografia reconocida y asumida como tal, muchos elementos auténticamente "vividos" animan a la novela tradicional, que es a la vez novela psicológica y realista, testimonio sobre la vida de provincia, la gran ciudad o los ámbitos específicos que frecuenta el autor. Muchos retoman asi la tradición de los grandes realistas, de Balzac a Dostoievski, con preocupaciones ligadas a su medio social; su historia personal, sus convicciones religiosas o políticas, o particularismos que garantizan a veces el éxito de librería.

Henri Troyat recuerda sus orígenes en sus grandes ciclos sobre la Rusia antes de la revolución bolchevique (Les semailles et les moissons, 1952-1956; La lumière des justes, 1959-1962), y describe con una lucidez a veces cruel la burguesía contemporánea en Les Eygletière (19651970). Roger Vailland, excelente estilista, quiso ser teórico y apóstol del libertinaje en la tradición de Stendhal y de Choderlos de Laclos. ${ }^{129}$ En Beau masque (1954), La loi (1957, Premio Goncourt), La fête (1960), La truite (1964), Vailland agrega a su herencia surrealista un cinismo total y un toque de moral existencialista. Nacido también en 1907, Roger Peyrefitte, que se habia revelado por su parte apóstol de los amores prohibidos (Les amitiés particulières, 1944), ejerce sus aptitudes satíricas en la crónica escandalosa de la época: Les ambassadeurs (1951), Les clefs de Saint-Pierre (1955), Les juifs (1965). Hervé Bazin e Yves Navarre ingresan estrepitosamente a la literatura, suscitando el escándalo con la descripción inclemente de relaciones violentas en el medio familiar, ${ }^{130}$ llegando al tema del incesto (Qui j'ose aimer, 1956); o en el caso de Navarre, ${ }^{131}$ del gueto homosexual; pero esta reivindicación, por justificada que sea, carece tanto del impacto lírico de Jean Genet, como de la exigencia literaria de Tony Duvert.

${ }^{127}$ M. BUTOR, “Una autobiografía dialéctica", en Répertoire I. París, Minuit, 1965.

${ }^{128}$ N. PIÉGAY-Gros, op. cit., p. 28.

${ }^{129}$ Escribió además la adaptación cinematográfica de Las relaciones peligrosas para Roger Vadim.

130 Vipère au poing (1948), La mort du petit cheval (1950), Au nom du fils (1961), Madame Ex (1975).

${ }^{131}$ Lady Black (1971), Le petit galopin de nos corps (1977), Le jardin d'acclimatation (1980, Premio Goncourt), Biographie (1981), Poudre d'or (1993). 
Françoise Mallet-Joris describe con talento diversos círculos de la sociedad. ${ }^{132}$ Con un éxito al que sustenta la precocidad, Françoise Sagan publica a los dieciocho años una excelente novela que describe con singular acierto la sensibilidad de una generación burguesa aburrida, ociosa y desengañada en medio de numerosas aventuras eróticas. Bonjour tristesse (1954), Un certain sourire (1956) son los primeros títulos de una carrera exitosa, aunque Un profil perdu (1974) y Le lit défait (1977) no susciten, dos décadas después, el mismo entusiasmo. Sagan, quien ha escrito también varias obras de teatro, ha publicado un libro de recuerdos en forma de ensayos: Avec mon meilleur souvenir (1984).

Robert Sabatier retoma con la trilogia de Olivier, el niño desdichado, ${ }^{133}$ una vieja receta de Dickens y la explota luego en Les fillettes chantantes (1980). En Les années secrètes de la vie d'un homme (1984), Sabatier renueva su estilo con un acercamiento original al género autobiográfico. Gilbert Cesbron conquista a sus lectores con el análisis cristiano de los problemas psicológicos y sociales más candentes: la infancia doliente, delincuente (Chiens perdus sans colliers, 1958), lastimada por los dramas de familia (C'est Mozart qu'on assassine, 1966), la evangelización de los obreros (Les saints vont en enfer, 1952), la guerra de Argelia (Entre chiens et loups, 1960).

Auguste Le Breton evocó sus recuerdos en libros sobre una niñez desdichada, antes de dedicarse a un tipo de novela policiaca violenta, donde abunda el caló o argot. Albert Simonin (Touchez pas au grisbi) y Frédéric Dard, el autor de la serie de San Antonio (que se inició en 1949 con Réglez-lui son compte), alcanzaron también, por la crudeza y el carácter cómico de su lenguaje, grandes éxitos de librería. En los años setentas, Jean-Patrick Manchette ${ }^{134}$ se propone, conscientemente y con mayores exigencias intelectuales, renovar el género policiaco con un estilo paródico y una interesante práctica de la intertextualidad: "servirse de una forma superada es utilizarla referencialmente, es honrarla al criticarla, al exagerarla, al deformarla por ambos lados".

A Dominique Fernández, el apóstol de una ebriedad por Italia (después de haber vivido un tiempo en este pais), lo consagra el éxito de Porporino ou les mystères de Naples (1974, Premio Médicis), aunque su

${ }^{132}$ Le rempart des béguines (1951), Les mensonges (1956), L'empire céleste (1958), Les signes et les prodiges (1966).

${ }^{133}$ Les alumettes suédoises (1972), Trois sucettes à la menthe (1972), Les noisettes sauvages (1974). Cf. Olivier et ses amis (1993).

${ }^{134}$ L'affaire N'Gusto (1971), Nada (1972), Le petit bleu de la côte ouest (1976). 
primera novela, $L$ 'écorce des pierres, remonte a 1959 . Su esteticismo no siempre exento de barroquismo preciosista, encontró un tono justo en la ironía y en la generosidad con la que detalla en La escuela del Sur (1991) los temas constantes en toda su obra. En términos stendhalianos, opone la ligereza, la alegría de vivir y también la inmadurez de una sociedad machista dominada por las mujeres, a "la escuela del norte", es decir, a la mentalidad francesa, rigurosa, egoísta, austera y racionalista. En una gran saga con trasfondo histórico, Dominique Fernández describe el encuentro tumultuoso de ambos mundos.

El éxito de Michel Tournier (nacido en 1942) en los años setentas, es decir, cuando la nueva novela había conseguido un amplio reconocimiento, impuso a un escritor que se presentaba paradójica y abiertamente como heredero del naturalismo y utilizaba los recursos más tradicionales de la escritura. "Mi propósito no es el de innovar en la forma, sino de transmitir en una forma tan tradicional, preservada y tranquilizadora como sea posible, una materia que no posee ninguna de estas cualidades". ${ }^{135}$

Su primer libro, Viernes o los limbos del Pacífico, seduce inmediatamente a Raymond Queneau, que lo publica en Gallimard (1967), y recibe ese mismo año el Gran Premio de la Academia Francesa. Aunque El rey de los alisios (1970, Premio Goncourt) remita por ciertos aspectos a la novela histórica (una infancia a principios de siglo, una juventud que se compromete con el nazismo) y Los meteoros (1974) a una novela realista, las obras de Michel Tournier evocan, todas, ${ }^{136}$ la narrativa filosófica, por la reutilización de mitos inquietantes (el Ogro, los Gemelos, el Andrógino, los Magos) que plantean problemas éticos, pero, comparados a los de Cesbron, Peyrefitte o Navarre, en una forma simbólica que les confiere una violencia descomunal.

\section{Novela histórica}

La permanencia de formas tradicionales se manifiesta también en el gran auge de la novela histórica, una receta infalible para complacer al público francés desde Alejandro Dumas. Su popularidad se explica por

${ }^{135}$ Michel Toumier, Le vent paraclet (1977).

${ }^{136}$ Ha publicado también: Le coq de bruyère (1978), Gaspar, Melchior et Balthazar (1980), Gilles et Jeanne (1983), Le vagabond immobile (1984), La goutte d'or (1986), Le médianoche amoureux (1989); dos libros de ensayos literarios: Le vent paraclet (1977) y Le vol du vampire (1981), y varios textos sobre la fotografia, como el último Le crépuscule des masques (1992). 
la manera en que permite conocer, apreciar y juzgar a los personajes del pasado confrontándolos con la sensibilidad moderna: los grandes ciclos de Maurice Druon (Les rois maudits, seis volúmenes, de 1955 a 1964) abarcan la vida de la corte francesa en el siglo xIV; los de GeorgesEmmanuel Clancier (Le pain noir, 1956-1964), la vida de los campesinos del siglo XIX; los libros de Françoise Mallet-Joris Les personnages (1961) y Marie Manicini (1965) evocan la época de Richelieu; los bestsellers de Jean Bourin ${ }^{137}$ restituyen acontecimientos de la vida en el siglo XIII y de la aventura de las cruzadas. Para continuar con ejemplos de una producción que le debe más al modelo exitoso de Cécil SaintLaurent (Caroline Chérie, 1947) que a la verdadera literatura, Françoise Chandernagor, ${ }^{138}$ por su parte, hace revivir a la sociedad del siglo XVIII, y Régine Desforges a la del periodo de la última gran guerra en los sucesivos volúmenes de su serie La bicicleta azul. ${ }^{139}$

Pero con Marguerite Yourcenar la novela histórica descubre su expresión más lograda y alcanza la excelencia de las verdaderas obras maestras. Por la profundidad de su documentación erudita, por el extremo cuidado de su estilo, Yourcenar analiza con acierto los sentimientos imperecederos que, como auténtica humanista, vuelve a encontrar en un emperador romano (Memorias de Adriano, 1955, famosas en los países de lengua española gracias a la notable traducción de Julio Cortázar) o en los personajes del siglo XVI (Opus nigrum: L'oeuvre au noir, 1972).

\section{La novela recobrada}

Para terminar este panorama, es preciso valorar una renovación de la novela, ya señalado en escritores tan disímiles como Sollers, Duras, Tournier, etcétera. Calvino leyó así La vie mode d'emploi (1979), la última gran novela de Perec, que es sin duda su obra maestra:

Otro ejemplo de lo que llamo "hipernovela" es La vida, instrucciones de uso (La vie mode d'emploi) de Georges Perec, novela muy larga pero construida con muchas historias que se entrecruzan (no en vano su subtítulo es Romans, en plural), haciendo revivir el placer de los grandes ciclos, a la manera de Balzac.

137 Très sage Héloise (1966), La chambre des dames (1979), Le jeu de la tentation (1981), Les pérégrines (1989) Les compagnons'd'éternité (1991).

${ }^{138} L$ 'allée du roi, recuerdos de Françoise d'Aubigné, marquesa de Maintenon (1982), $L$ 'enfant aux loups (1990).

${ }^{139}$ La bicyclette bleue (1981), 101, avemue Henri Martin (1983), Le diable en rit encore (1985). Publicó después Noir tango (1991). 
Creo que este libro, aparecido en París en 1978, cuatro años antes de que el autor muriera con sólo cuarenta y seis años, constituye el último verdadero acontecimiento en la historia de la novela. Y por muchas razones: el plan inmenso y al mismo tiempo terminado, la novedad de la manera de abordar la obra literaria, el compendio de una tradición narrativa y la suma enciclopédica de saberes que dan forma a una imagen del mundo, el sentido del hoy que está también hecho de acumulación del pasado y de vértigo del vacio, la presencia simultánea y continua de ironía y angustia, en una palabra, la forma en que la prosecución de un proyecto estructural y lo imponderable de la poesía se convierten en una sola cosa. ${ }^{140}$

Daniel Pennac, nacido en 1944, se transformó repentinamente en autor de best-sellers, con dos títulos en el primer rango de los libros de bolsillo más vendidos del año 1992:141 La fée carabine (1987) y sobre todo La petite marchande de prose (1989). Este último ilustra de manera amena e irónica, en un verdadero aunque burlesco homenaje a la novela, que mezcla el tono de lo policiaco a la San Antonio (el polar) y la parodia épica manejada treinta años antes por Queneau en Zazie dans le métro, los temas de la pasión por la escritura, el bullicio editorial, el delirio publicitario y el frenesí del público por los best-sellers. De su ensayo Comme un roman (1992) se vendieron sobre la marcha más de 200000 ejemplares.

Sin embargo, una obra sintomática del momento histórico que atraviesa el quehacer literario contemporáneo merece un examen más detallado: la de Jack-Alain Léger. ${ }^{142}$

En 1989, año del Bicentenario de la Revolución Francesa y del triunfo del Siglo de las Luces, Jack-Alain Léger daba a su decimoquinta novela un título elocuente: Le siècle des ténèbres (El siglo de las tinieblas). A contracorriente de las modas y las complacencias modernas, en ella elabora una crítica aguda y feroz, incluso divertida, del establishment literario e intelectual de Occidente. Aunque sólo uno de sus libros aparezca como una pesquisa autobiográfica (Autoportrait au loup, 1982),

${ }^{140}$ I. Calvino, op. cit., p. 135.

${ }^{141}$ La misma encuesta (de la sociedad Tite-Live) coloca a Marguerite Duras en doceavo lugar con Los impudentes.

142 Jack-Alain Léger nació en Sanary en 1947. Ha recorrido con fervor toda la vieja Europa, gravitando sobre los polos que orientan las referencias culturales de su obra: Viena, Venecia, Sils-María, Florencia, Praga. Ha vivido en París, en Quebec, en las laderas del Mont-Blan, y de nuevo en París. 
todas las novelas que Jack-Alain Léger ha escrito con diversos seudónimos (Melmoth, Dashiell Hedayat) - pues como Stendhal, se esconde exhibiéndose - retornan incesantemente a los dramas de su propia vida. Bajo diversas máscaras pone en escena al héroe puro que en continuo desacuerdo con un mundo de falsarios y felones, sin lugar para los héroes, emprende un combate contra molinos de viento. Como Lanier Diver en Selva oscura (1974), Guido en Océan boulevard (1982), Élie en Pacific palisades (1984), Bruno Arhein en Wanderweg (1986), el narrador del Autoportrait o del Siècle es un artista, o un esteta, que ve en el arte -o en la escritura como último recurso- un postrer desafío a la decadencia y la muerte. Son todos ellos hombres extraviados en la profundidad del bosque interior o en la jungla social, y padecen por igual el malestar de la cultura.

La obra de Jack-Alain Léger parece estructurada al modo de una Divina comedia al revés, cuyo punto final es el infierno y su guía un Virgilio que esgrime las imágenes de un paraíso cultural perdido. En esta obra, donde Don Quijote y La divina comedia funcionan como dos modelos novelescos permanentes, se produce una constante interpretación de lugares, épocas y personajes, así como del mundo del arte y del mundo real. La continua tensión - sonrisa a punto del llanto, rostros como destellos arrancados a la oscuridad- nos remite al numen con el que, según Starobinski, Tiépol o dibuja esqueletos y mariposas nocturnas en las últimas fiestas de la República de Venecia. ${ }^{143}$

A contracorriente también de lo que constituía una cierta vanguardia literaria en la época de sus primeras novelas, Jack-Alain Léger no busca innovaciones formales, aunque gustoso cultiva un género híbrido que combina el ensayo literario o filosófico con la novela tradicional. Se limita a escribir bien, pero siguiendo los pasos de Flaubert, de Proust, incluso de Saint-Simon: a costa de una labor con el lenguaje, que recuerda a Michel Leiris y donde se percibe la doble mirada del que analiza, oyéndose hablar y bajando, a lo largo de los rodeos y atajos de su propio discurso, a los avernos -o a los reversos- de su propio yo. Jack-Alain Léger es ante todo un estilista, pero entre sus manos el estilo se vuelve auténtico estilete, arma, bisturi; $;^{144}$ se trata a final de cuentas de un

143 Jean STAROBINSKI, Les emblèmes de la raison. París, Flammarion, 1973 (Champs), pp. 17-22.

144 René Char aprovechaba ya en "La biblioteca está ardiendo" la extraordinaria ambigũedad del sentido: "mon métier est un métier de pointe". (La parole en archipel, p. 378.) 
moralista que combate a vuelta de página la estupidez, la vulgaridad, la cobardia y la deshonestidad intelectuales.

Una de sus últimas obras, tituladas significativamente La novela, ${ }^{145}$ proclama: "no le tengamos miedo a lo novelesco", y reclama esa categoría como forma de vida: como posible salida a los diversos impasses de la modernidad. Como Lichtenberg y como Cioran (Syllogismes de l'amertume, 1952), el novelista explora últimamente el género del fragmento en clips que persiguen, como las grandes novelas pero con la energía del texto lapidario, el escrutinio del delirio de la modernidad.

\section{La escritura en suspenso}

1. El panorama de la modernidad literaria en Francia sería incompleto sin una ubicación pertinente del posmodernismo, palabra en boga que ha sustituido a las fórmulas nueva novela, nueva crítica, nuevos filósofos, etcétera, y aparece como uno de los tópicos favoritos de los ochentas y noventas. En esa noción confusa se enmaraña nuestro fin de milenio.

La palabra posmodernismo ha suscitado tantas interpretaciones diversas y divergentes que la mejor manera de entenderla con claridad es retomando las cosas desde el principio. Las crisis de la modernidad desembocan en un rechazo de lo moderno, que es el llamado posmodernismo. Confusiones y ambigüedades empiezan, por ende, en lo que se considera "moderno". Según una costumbre ampliamente compartida, opuse en este texto lo moderno a lo tradicional, presuponiendo como moderno lo que rompe con la tradición. ${ }^{146} \mathrm{Si}$ bien la tradición se define como la transmisión de un modelo, la modernidad -en este caso la modernidad literaria - es 10 que manifiesta una ruptura profunda. Al considerar aquí, con fines prácticos, sólo la ruptura de los años cincuentas, no pretendo eludir que la modernidad nació realmente con la refutación del academismo, cuando en la segunda mitad del siglo XIX $l o$

145 Jack-Alain LÉGER, Le roman. París, Olivier Orban, 1991. Ha publicado después Les souliers rouges de la duchesse (1992) y Jacob Jacobi (1993). Traducidos al español (Barcelona, Argos/Vergara): Monsignore (1977), Capriccio (1979) Un cielo tan frágil y Mi primer amor (1977).

146 En el siglo XV, el cristianismo esgrimía ya esta palabra para reclamar la necesidad de una devotio moderna. A fines del XVII, la Academia Francesa fue la sede de una "querella de los antiguos y los modemos". El modernismo reapareció también, en los primeros años del xx́, como una corriente de la Iglesia católica. 
nuevo apareció como un valor en sí -credo del cual Baudelaire y Rimbaud fueron los primeros heraldos. ${ }^{147}$

Sin embargo, Octavio Paz y los estadounidenses hablaron de "tradición moderna", definiéndola como una "tradición de la ruptura" ${ }^{148} \mathrm{La}$ tradición moderna está hecha de varias crisis: en Las cinco paradojas de la modernidad, Antoine Compagnon distingue cinco principales, que subrayan cinco paradojas de la modernidad. El modernismo posromántico corresponde a la superstición de lo nuevo; el cubismo de 1910, a la religión del futuro; el surrealismo ilustra en los años treintas la manía historicista y teoricista; en los años cincuentas, es el llamado a la cultura de masas; en el posmodernismo de los años noventas, la pasión por el reniego.

En su definición más sencilla, al posmodernismo, un movimiento que rechaza el modernismo del siglo $\mathrm{XX}$, lo representan típicamente obras que expresan una negación y una reivindicación de posturas del pasado. Fue en los años setentas - primero en Estados Unidos, luego en Francia-cuando el término posmodernismo recibió un sentido laudativo. ${ }^{149}$ En Francia, es una arquitectura deseosa de romper con el funcionalismo internacional. La modernidad arquitectónica había significado en efecto "el rechazo a los excesos decorativos y la búsqueda de líneas y volúmenes simples, la adaptación de la forma a la función". ${ }^{150}$ Por 10 tanto, el posmodernismo se define primero por lo que desecha: el dogma de la necesaria e incesante renovación, la deshumanización del arte moderno -que en la arquitectura produjo edificios inhabitables-y ia unidad de estilo, esa pureza que llevó el arte moderno a cierta austeridad.

Aparte de esa caracterización negativa, el posmodernismo se define

${ }^{147}$ Antoine COMPAGNON, Les cinq paradoxes de la modernité. París, Le Seuil, 1990,p. 9. Ver también Josep PiCó, Modernidad y posmodernidad. Alianza, 1989. Cf. Rimbaud: "Il faut être absolument moderne". (Une saison en enfer, p. 452.) Baudelaire: "[...] il y a un élément nouveau, qui est la beauté moderne". (Oeuvres complètes, Plèiade, p. 952.) Y los últimos versos de Las flores del mal: "Plonger au fond gouffre, Enfer ou Ciel, qu'importe? / Au fond de l'Inconnu pour trouver du nouveau!"

148 "Tradición no es continuidad sino ruptura y de ahí que no sea inexacto llamar a la tradición moderna: tradición de la ruptura". (Octavio PAZ, Corriente alterna. México, Siglo XXI, 1976, p. 19.)

149 Ihab HASSAN, The dismemberment of Orpheus: Toward a Postmodern Literature, 1971; Jean-François LYOTARD, La condition postmoderne, rapport sur le savoir. París, Éditions de Minuit, 1979. 109 pp.

${ }^{150}$ François Tomas, Paris-México: la primera modernidad arquitectónica. México, UAM/IFAL/Colegio de Arquitectos, 1993, p. 61. 
también por lo que defiende, promueve o busca: al privilegiar un método suave y sin pretensiones, "se conformará con una arquitectura modesta y fragmentaria y se mezclarán los códigos, reevaluando la ambigüedad, la pluralidad y la coexistencia de los estilos"; "reivindica el derecho al eclecticismo, al localismo y a la reminiscencia, y reclama para sí un sincretismo tolerante"; cultiva al mismo tiempo el pastiche, la parodia, la cita vernácula y la cita histórica. ${ }^{151}$ Son así características del posmodernismo la nostalgia por las formas del pasado y la reivindicación de afinidades con otras tradiciones arquitectónicas, como el barroco, el manierismo o el propio modernismo, que ya pertenece a la tradición y es, por lo tanto, como forma histórica entre otras, un elemento del patchwork posmodernista. ${ }^{152}$

Uno de los primeros autores que aplicaron esa noción a la literatura fue el escritor estadounidense John Barth, cuyas propuestas responden a la intención del presente ensayo. ${ }^{153} \mathrm{Al}$ criticar el agotamiento de las formas de la modernidad, John Barth exige una literatura agradable, de convivencia, que procure gusto al lector, así como los arquitectos posmodernos se preocupan por el bienestar de los habitantes en sus edificios. En ese sentido, se reivindica como posmodernos a García Márquez, Borges, Nabokov, Beckett, Italo Calvino. ${ }^{154}$ Aunque su interpretación del posmodernismo se apoye en una definición reduccionista, ${ }^{155}$ éste último es tal vez quien presenta globalmente la mejor ilustración de la estética posmoderna, tanto en su método de análisis ${ }^{156}$ como en los valores que recomienda para el futuro en sus Seis propuestas para el próximo milenio: levedad, rapidez, exactitud, visibilidad, multiplicidad, consistencia.

En la acepción amplia de la palabra, es posmoderno también el recelo hacia las grandes teorizaciones sobre las que descansaba la modernidad.

151 "La cita es la más potente de las figuras posmodernas". (A. COMPAGNON, op. cit., p. 151.)

152 Cf. Ibid., pp. 147,148 y 150.

153 The literature of exhaustion and the literature of replenishment (1982).

154 En Europa, esos escritores son más bien considerados como "modernos".

155 "Reciclar las imágenes usadas en un nuevo contexto que les cambie el significado. El post-modernism puede considerarse la tendencia a hacer un uso irónico de lo imaginario de los mass-media, o bien la tendencia a introducir el gusto por lo maravilloso heredado de la tradición literaria en mecanismos narrativos que acentúen su extrañamiento". (I. Calvino, op. cit., p. 110.)

${ }^{156}$ Además de ejemplos tomados de Gadda, Perec o de su propia obra, Calvino rescata al mismo tiempo citas y conceptos de los clásicos Dante, Leopardi, Cavalcanti, etcétera. 
Como lo apuntó René Schérer, ${ }^{157}$ el espíritu posmoderno, hecho de seriedad y cálculo, es "realista" en la medida que, rebelde a las ilusiones, ya no cree en las grandes utopias políticas que pretendieron rehacer el mundo. Este movimiento fue identificado por Marcuse desde fines de los sesentas, en una conferencia dictada en la Universidad de Berlin e intitulada "El fin de la utopía". La crisis del marxismo y la caída de un régimen soviético basado en el discurso leninista, serían en este sentido acontecimientos "posmodernos".

Mientras las vanguardias nos remiten generalmente a la noción de modernidad, muchas obras literarias en este siglo XX reflejaron lo que ahora se define como posmoderno: mezcla de estilos, práctica de la intertextualidad por las formas del pasado, etcétera. Al lado de la modernidad, sin que sea necesariamente después de ella, parece manifestarse constantemente un antimodernismo, un posmodernismo. Sin embargo, la palabra misma nos sitúa en un después, convocando asi a un balance de la civilización occidental, cuyos disjecta membra pretende retomar. ${ }^{158}$ El posmodernismo sería la forma actual del milenarismo, la conciencia de que el fin de este segundo milenio es el fin de un mundo.

El milenio que está por terminar vio nacer y expandirse las lenguas modernas de Occidente y las literaturas que han explorado las posibilidades expresivas, cognoscitivas e imaginativas de esas lenguas. Ha sido también el milenio del libro; ha visto cómo el objeto libro adquiria la forma que nos es familiar. La señal de que el milenio está por concluir tal vez sea la frecuencia con que nos interrogamos sobre la suerte de la literatura y del libro en la era tecnológica llamada postindustrial. ${ }^{159}$

¿Quién podría proporcionar a este capítulo una mejor conclusión? Hablé de la aparición de la escritura y de la invención de la imprenta en los albores de nuestra civilización; mencioné esa reflexión sobre la

${ }^{157}$ René SCHÉrer, Pari sur l'impossible. París, Presses Universitaires de Vincennes, 1989, p. 6 .

158 Algunas referencias cinematográficas: Blade runner (1982, de Ridley Scott, con Harrison Ford), en la ciudad neogótica de Batman (1989, de Tim Burton, con Michael Keaton y Jack Nicholson; menos "posmoderna" y menos lograda en mi opinión, Batman returns, 1992, con Michael Keaton, Michelle Pfeiffer y Dany de Vito), las visiones apocalípticas de Mad Max (1979, de George Miller con Mel Gibson; y especialmente Mad Max 2, 1981), etcétera.

${ }^{159}$ I. Calvino, op. cit., p. 11. 
literatura que hace surgir el concepto de escritura en el crepúsculo de la era del libro. La crisis de la civilización occidental propició un cambio de perspectiva en la doble convulsión de 1914 y 1939: desde el principio de un siglo XX caracterizado por la descolonización, la aparición de una nueva ciencia del hombre fue prueba de una descolonización intelectual (mientras los artistas cubistas habian anunciado una descolonización estética), es decir, del reconocimiento de la existencia del Otro, de la independencia y soberanía de civilizaciones antes consideradas como primitivas e inferiores, y por ello sometidas a Occidente.

2. Cada cultura debe forjar los valores estéticos y filosóficos que conforman su identidad. Este fin del siglo xx parece sufrir cierta incapacidad de crear y por 10 mismo cierta falta de identidad. ¿Será el posmodernismo una cultura, o más bien una repetición endeble de las formas del pasado? (es decir, una suerte de narcisismo, espontánea confesión de impotencia). El gigantismo y la multiplicación de los museos, de las bibliotecas, la museificación de nuestras ciudades, e incluso el gusto por la cita, son tal vez la señal de una verdadera museificación de la cultura. El disco compacto, el video, el walkman, permiten conservar imágenes y sonidos con una fidelidad de la que en los años cincuentas e incluso setentas apenas se tenía idea. En lugar de cantar o de improvisar con algún instrumento, es frecuente escuchar grabaciones de alta fidelidad; en lugar de inventar poesía, buscar citas en las antologías; en lugar de decorar las paredes de las casas, acudir confusamente a la proliferación de los facsímiles. La reproducción ahoga la producción. La boga de las referencias rescatadas del pasado traduce la obsesión de llegar después y revela la impotencia para imaginar el porvenir, es decir, para inventar. "Uno de los rasgos distintivos de este fin de siglo es, sin lugar a dudas, su impotencia para especular sobre el porvenir". .60

Por lo tanto, el pensamiento contemporáneo se ha vuel to "probabilista", enfocado a calcular lo probable, día por día, a partir de la masa de informaciones del pasado, 10 cual excluye cualquier audacia en la idea y desconoce adrede la riqueza de 10 posible. ${ }^{161}$

160 "Un des traits marquants de cette fin de siècle est, sans conteste, son impuissance àspéculer sur l'avenir. [...] Le discours des lendemains est caduc". (R. SCHÉRER, op. cit., p. 5.)

161 "Nuestro pensamiento se ha obligado a funcionar "al dia", sin mayor horizonte que una previsión meteorológica [...] es probabilista, con el añadido que ello confiere a un tipo 
Las grandes innovaciones de la escritura moderna habian sido la obra de algunos fundadores (Proust, Valéry, Gide, Céline, Char, Michaux, Ponge, etcétera), pero la producción literaria desde 1950 recogió la herencia de movimientos (la $N . R$. F., el surrealismo, el existencialismo) que lejos de participar todos de la modernidad, se reclamaron a veces de una tradición más antigua: el realismo, la novela psicológica, la novela histórica. La valoración de lo novelesco, el desarrollo y la transformación del género autobiográfico, son contemporáneos de una escritura experimental que acaba por aniquilarse, y parecen ser la única respuesta contemporánea, no sólo al deseo de recuperar aquel sujeto del discurso que la modernidad había escam oteado (el regreso de Marguerite Duras a la forma autobiográfica le valió, con el Goncourt, una audiencia que no habia tenido durante la "nueva novela"), sino también el desengaño posmodernista, a la desaparición del sentido de la historia. En efecto, como lo subraya René Schérer en su Pari sur l'impossible (Apuesta sobre lo imposible), la desagregación de la utopía en lo político deja abierta una reivindicación de la utopía en el terreno de lo que Charles Fourier llamaba "lo doméstico", es decir, la organización de lo cotidiano por el mecanismo pasional, campo por excelencia de la narrativa. "Ya no es el sujeto el que cuenta, aquel sujeto egoista [...] que necesitan la metafísica, la ética y el derecho, sino las atracciones constitutivas de la complejidad, de la fluidez humana. Éstas permiten practicar, tanto en el espacio de la sociedad como en la infinidad de los universos, una disposición nueva". 162

Por un fenómeno que parece característico del siglo $\mathrm{XX}$, aunque presente ya en otras épocas (como el siglo XVI, cuando se leían más obras clásicas que textos contemporáneos), en este siglo de consumo masivo, la cultura de mayor circulación no es siempre la que se produce en la actualidad. Las estadísticas revelan que los grandes éxitos de librería no son las obras "modernas" (en 1957, de La celosia se vendieron apenas 1000 ejemplares), sino las más tradicionalistas o las del pasado: en los sesentas, la proporción de las reediciones o reimpresiones llegó a

científico de conocimiento y con el rechazo de cualquier audacia en la idea; lo probable opone su determinación - calculada según el cúmulo de informaciones pasadas - a la riqueza de lo aleatorio, a la eventualidad de lo totalmente otro". (Idem.)

162 "Ce n'est plus le sujet qui compte, ce sujet égoīste - mouvement arrêté ou contractédont la métaphysique, la morale et le droit ont besoin, ce sont les attractions constitutives de la complexité, de la fluidité humaines. Elles permettent de pratiquer, dans l'espace social comme dans l'infinité des univers, un nouveau découpage”. (Ibid., p. 200.) 
representar, con el desarrollo de las colecciones de bolsillo, la mitad de la producción literaria global.

Esa situación, conforme a un aspecto del posmodernismo, ya se vislumbraba en el periodo de la llamada "modernidad". Desde los cincuentas, se considera un récord la impresión en 1000 ejemplares de un libro de poemas. En cambio, Arthur Rimbaud se imprime a 400000 ejemplares en colección de bolsillo. ${ }^{163}$ En el caso de la novela, todavía más significativo, llegan primero, aparte del récord absoluto de Cécil Saint-Laurent (Caroline chérie: 7000000 de ejemplares vendidos de 1947 a 1992), ${ }^{164}$ novelas de gran calidad literaria, pero de factura "tradicional", publicadas en el periodo de la guerra, justo antes de los cincuentas: El extranjero (6 500000 ejemplares vendidos de 1942 a 1992) y La peste (5 300000 ejemplares vendidos de 1942 a 1992, mientras de 1942 a 1956 se habían vendido 360000 -lo cual significa que sólo entre 1956 y 1992 ise vendieron casi 5000 000!); El principito, de Saint-Exupéry (5 800000 ejemplares vendidos de 1946 a 1992); $E l$ silencio del mar, de Vercors (que tenía el primer lugar en 1982 con 2746000 ejemplares, llega en 1992 a 4300000 ejemplares vendidos desde 1942); El Grand Meaulnes, de Alain-Fournier (4000 000 de ejemplares vendidos de 1913 a 1992); La condición humana, de Malraux (3 500000 ejemplares vendidos de 1942 a 1992). Inmediatamente después vienen las grandes novelas realistas del siglo XIX: Zola: Germinal (3 200000 ejemplares vendidos hasta 1992) y La taberna (2000 000 de ejemplares vendidos hasta 1982, mientras hasta 1929 sólo se habian vendido 200 000), y luego las de Balzac y Stendhal. Si nos limitamos a la producción contemporánea, los best-sellers ${ }^{165}$ promueven una literatura bastante mediocre, con algunas excepciones: El amante de Marguerite Duras rebasó los 2200000 ejemplares con la salida de la película de Jean-Jacques Annaud en enero de 1993; pero Frédéric Dard vendió 200000000 de títulos, y la trilogía de Régine Desforges, La bicicleta $a z u l$, vendió en total 6300000 ejemplares. Vipère au poing de Hervé Bazin fue impresa con un tiraje de 700000 ejemplares, cifra que alcanzan Roger Peyrefitte o Michel de Saint-Pierre. En 1992, se vendie-

${ }^{163}$ Ese récord no es motivado por el Centenario de Rimbaud en 1991, ya que estas cifras son las de 1982. El segundo lugar lo tiene Eluard, con 300000 ejemplares.

${ }^{164}$ En forma de consuelo, si se suman las siete novelas que constituyen En busca del tiempo perdido, ise alcanza el número de 8000000 de ejemplares vendidos de 1913 a $1992 !$

${ }^{165} \mathrm{Un}$ best-seller se define por un promedio de venta de 50000 ejemplares. 
ron 240000 ejemplares de Les compagnons d'éternité, de Jeanne Bourin, mientras que del último Le Clézio (Etoile errante) se imprimieron 110000 ejemplares.

El apego del público a las formas tradicionales expresa entonces cierto fracaso de las vanguardias literarias del siglo XX, lo que nos plantea una interrogación final: ¿será legítimo hablar de una "invención" de la escritura? En efecto, es difícil, en esas condiciones, admitir que se haya inventado un instrumento capaz de dejar huellas durables, excepto en el campo de la reflexión sobre la literatura.

Alguien advirtió que el verdadero inventor de la escritura no fue el oscuro egipcio que trazó los primeros jeroglíficos, sino Champollion, quien supo descifrarlos. En efecto, Champollion integró esa escritura al patrimonio de la humanidad al transformar graffiti, sin sentido para nosotros, en un medio de comunicación con el pasado. De manera comparable, los críticos y los escritores que dieron sentido a la escritura contemporánea fueron tal vez sus verdaderos inventores. Sólo se puede hablar de "invención de la escritura" refiriéndose, un poco como Edmundo O'Gorman que mantiene la ambigüedad de su libro La invención de América, ${ }^{166}$ a la conceptualización de una realidad ya existente (etimológicamente, inventar es encontrar: invenire), pero que todavía no tiene función alguna en el universo del hombre. Al darle sentido, quienes la definieron la integraron a la representación del mundo.

Sin embargo, incluso en esa acepción del término, dicha "invención" merece signos de interrogación. Cabe en efecto preguntarse si al pretender haber encontrado una nueva escritura, la modernidad no estuvo en realidad a punto de perder el uso de la palabra. “¿Cómo llegó a mí la escritura? Como un plumón sobre mi ventana, en un invierno. Súbitamente en el atrio surgió una batalla de tizones que hasta el momento no ha concluido". ${ }^{167}$

${ }^{166}$ Edmundo O'GoRMAN, La invención de América. México, FCE, 1958.

167 "Comment me vint l'écriture? Comme un duvent d'oiseau sur ma vitre, en hiver. Aussitôt s'éleva dans l'âtre une bataille de tisons qui n'a pas encore à présent, pris fin". ( $R$. CHAR, "La bibliothèque est en feu", en La parole en archipel, p. 377.) 